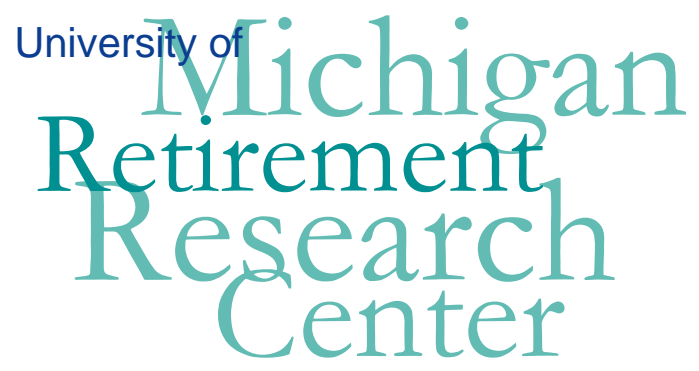

Working Paper

WP 2008-196

\title{
Pension Reform in Mexico: The Evolution of Pension Fund Management Fees and their Effect on Pension Balances
}

Emma Aguila, Michael D. Hurd and Susann Rohwedder

\begin{tabular}{|l|l|}
\hline $\mathrm{M}$ & $\mathrm{R}$ \\
\hline $\mathrm{R}$ & $\mathrm{C}$ \\
\hline
\end{tabular}$\quad$ Project \#: UM08-16 


\title{
Pension Reform in Mexico: The Evolution of Pension Fund Management Fees and their Effect on Pension Balances
}

Emma Aguila

RAND

Michael D. Hurd

RAND and NBER

Susann Rohwedder

RAND

September 2008

\author{
Michigan Retirement Research Center \\ University of Michigan \\ P.O. Box 1248 \\ Ann Arbor, MI 48104 \\ http://www.mrrc.isr.umich.edu/ \\ (734) 615-0422
}

\section{Acknowledgements}

This work was supported by a grant from the Social Security Administration through the Michigan Retirement Research Center (Grant \# 10-P-98362-5-04). The findings and conclusions expressed are solely those of the author and do not represent the views of the Social Security Administration, any agency of the Federal government, or the Michigan Retirement Research Center. 


\title{
Pension Reform in Mexico: The Evolution of Pension Fund Management Fees and their Effect on Pension Balances
}

\author{
Emma Aguila, Michael D. Hurd and Susann Rohwedder
}

\begin{abstract}
In 1997 Mexico introduced Personal Retirement Accounts (PRAs) which, after a transition phase, will completely replace the pay-as-you-go (PAYG) system. We give a detailed overview of the relevant institutional framework, the market of PRA providers and how it has evolved since the 1997 reform. We use administrative data obtained from CONSAR, the regulatory agency of the PRA system to assess how pension fund management fees affect pension accumulations. We find that fees can drain up to a quarter of individuals' pension savings.
\end{abstract}

\section{Authors’ Acknowledgements}

We thank Norely Corral for her excellent research assistance. 


\section{INTRODUCTION}

The introduction of individual or personal retirement accounts (PRA) has been considered as one important reform option for the U.S. Social Security program. There are a number of issues related to PRA schemes that make studying other countries' experiences with PRAs highly instructive for policy makers in the U.S. in order to avoid certain pitfalls of implementation, should this option be considered further, or to add policy designs that remedy some disadvantages. For example, PRA schemes in their purest form do not leave room for redistribution. Mexico has implemented a minimum pension benefit to provide for those with otherwise insufficient pension income.

The PRA design in Mexico is based on three pillars: first, a flat rate minimum floor that is the minimum pension guaranteed by the government; second, personal retirement accounts managed by private pension fund managers, and third, voluntary saving accounts for retirement (World Bank, 1994). In the case of public pension systems, in the pure design of defined benefit (DB) plans, the risk is borne by the government. The PRA system distributes the risk of saving for retirement in a different way compared to DB schemes. In the first pillar, the government bears the risk for lower-income workers guaranteeing a minimum pension for those most disadvantaged in the labor market. The second pillar, introduces financial instruments for saving for retirement and the risk is borne by the employee. The third pillar provides complementary saving options to the mandatory second pillar for saving for retirement with the benefit of tax advantages. In the U.S. tax favored voluntary saving options have been available in the form of 401(k) plans and Individual Retirement Accounts for over 30 years.

In 1997 Mexico introduced Personal Retirement Accounts (PRAs) which, after a transition phase, will completely replace the pay-as-you-go (PAYG) system. We use administrative data obtained from CONSAR, the regulatory agency of the PRA system to assess how pension fund management fees affect outcomes.

We find that fees drain pension accumulations by up to 25 percent of what would have been accumulated without fees. As a result many individuals, especially of the transition generation, will receive only the minimum pension guarantee because their accumulations will not be sufficient to fund a higher pension. The extent of this happening is important to gauge the additional cost to the government. Irrespective of the 
accumulated pension balances, the fees lower well-being during retirement, in some cases significantly so.

The paper is organized as follows. The next section presents an overview of the institutional framework in Mexico. The third section describes the PRA system, the evolution of pension fund managers and their market shares, fee structures, switching behavior of individuals in the system, interest rates, and investment portfolio composition. Section 4 presents the analysis of the impact of fees on the accumulation of pension funds. Finally, we offer a brief conclusion and discussion.

\section{INSTITUTIONAL BACKGROUND}

In Mexico, social security is mainly provided by the Mexican Social Security Institute (IMSS) for private sector workers and the State Workers Security and Social Services Institute (ISSSTE) for public sector employees. In 1997, the Mexican Social Security Institute (IMSS) reformed the PAYG pension system to be transitioned to a fully funded system based on personal retirement accounts (PRA). The Mexican Social Security Institute covers private sector workers who account for 38 percent of the labor force in Mexico. ISSSTE reformed its PAYG system into a PRA system in March 2007 that covers approximately $5.7 \%$ of the labor force. In this study we focus on IMSS pension system because the reform was implemented 11 years ago and this social security institute has the highest coverage of the labor force.

The PRAs are managed by private retirement fund managers (AFORES). The reform affected all workers who had not yet claimed their public pension as off July $1^{\text {st }}$, 1997. Workers who contributed previously to the PAYG can choose at the time of retirement whether to claim benefits under the PAYG or the PRA regime. ${ }^{1}$ We refer to these individuals as the transition generation. The IMSS computes the PAYG pension and the pension fund manager presents the PRA options of annuitization or scheduled withdrawals provided by insurance companies. The individual has 30 days to notify IMSS and the pension fund manager of the decision to opt for the PAYG or PRA. Workers who started contributing to the pension system after 1997 can only retire under the PRA rules (Aguila, 2000; Aguila, 2008). We refer to these individuals as the new generation.

\footnotetext{
${ }^{1}$ This is the case as long as they satisfy the minimum requirements to claim a pension in the PRA plan. Those persons that do not meet the requirements of the PRA system can only retire under the PAYG scheme.
} 
The PRA system in the Mexican case has some redistributive components: a) a monthly social quota deposited in the individual account, equivalent to $5.55 \%$ of the minimum wage of Mexico City, and b) a minimum pension guarantee equivalent to the minimum wage. Individuals obtain an annuity of at least the minimum wage of Mexico City. Chile was the first country to introduce this type of pension reform from a PAYG to PRA. The Chilean pension system includes some redistributive components such as the minimum pension guarantee and a guaranteed minimum rate of return for pension funds. In the Chilean case, the minimum pension guarantee represents approximately $62 \%$ of the minimum wage but in Mexico, the minimum pension guarantee is equivalent to a $100 \%$ of the minimum wage. Mexico does not have a guaranteed minimum rate of return for pension funds, but the government contributes to individuals' accounts the equivalent of 0.425 percent of a worker's wage and the monthly social quota (Aguila, Attanasio, and Quintanilla, 2008). In the Mexican case, employees bear all the financial risk with a lower bound provided by the minimum pension guarantee.

To qualify for a pension under the PRA system a worker has to contribute for a minimum of 1,250 weeks which is approximately 25 years. The PAYG required only 500 weeks (approximately 10 years), and the normal retirement age is 65 in both PAYG and PRA. Early retirement is possible in the PRA system from age 60 if the individual has a sufficient balance in the individual account to obtain a pension at least equivalent to the minimum pension guarantee. Early retirement at any age is available when the person can fund a pension of at least $130 \%$ of the minimum pension guarantee with the funds in the personal retirement account. The PRA system completely changes retirement incentives. This rule abolishes the notion of a normal or early retirement age for those that have saved enough to obtain a pension at least equivalent to $130 \%$ of the minimum pension guarantee. ${ }^{2}$ In the PAYG system, for each year that a person retires before the normal retirement age pension benefits are reduced by 5\%. At age 60 pension benefits reduced for early retirement amount to $75 \%$ of the normal retirement pension.

Contributions to the pension system are defined as a percentage of workers' earnings. The employer, employee and government contribute to the pension system. The

\footnotetext{
${ }^{2}$ In the Chilean case, there is also no particular retirement age for those individuals who can finance a pension of $150 \%$ of the minimum pension guarantee. This seems a stricter requirement than in the Mexican case but the minimum pension guarantee in Chile is worth less than $100 \%$ of the minimum wage (Aguila, Attanasio, and Quintanilla, 2008).
} 
employee and employer contributions did not change after the pension reform, remaining at 10.075 percent of a worker's wage. The government contribution to the PAYG was 0.425 percent of a worker's wage. With the introduction of the PRA the government contributes the social quota equivalent to $5.55 \%$ in addition to the 0.425 percent of worker's wage.

The government agency in charge of monitoring the performance of the PRA system in Mexico is the National Commission of Saving for Retirement (CONSAR) founded in 1994. In the next section we explore the administrative records of the performance of the PRA system obtained from CONSAR.

\section{PERSONAL RETIREMENT ACCOUNTS SYSTEM}

In this section we focus in the second pillar of the Mexican PRA system, which consists of the personal retirement accounts managed by pension fund managers. We describe the evolution of the number of pension fund managers, fees charged to the individual retirement accounts by pension fund managers, switching behavior of participants of the system, and the rate of return and investment portfolio of pension funds.

In February 2008, the PRA system in Mexico had 38.8 million participants. Figure 1 shows the evolution of the number of registered persons from 1998 to 2008. The number of participants has increased at an average monthly rate of 1.0 percent. Table 1 presents the number of participants by pension fund manager. Many AFORES started operations between 2004 and 2006. It is important to highlight that the PRA system reports the number of accounts in the system but some of the accounts are not active. Mexico has a high turn-over of labor and constant migration between the formal and informal sectors. This causes some workers to contribute only for short periods of time in the formal sector. As a result there is a large difference between the number of registered persons and those contributing. According to the latest available figures from CONSAR 83\% of persons registered were actively contributing to the system in July $2003 .^{3}$

The amount accumulated in the PRA system has grown in importance. Table 2 shows the amount accumulated in the PRA system from 2000 to 2008 for mandatory and voluntary contributions. Voluntary contributions are still a small fraction compared to

\footnotetext{
3 Aguila, Attanasio and Quintanilla (2008) show that the gap between persons registered and those contributing grows considerably from 1997 to 2005. By 2004, only 51.5\% of persons registered to the PRA system are actually contributing.
} 
mandatory saving. These figures illustrate the growing importance of PRAs in transitioning towards a funded pension system.

\subsection{Evolution of Pension Fund Managers and their Market Share}

The PRA system started in July 1997 with 17 pension fund managers (AFORES). From 1997 to 2002, those with the lowest market share merged with some of the existent AFORES. In December 2003, only 11 AFORES remained. ${ }^{4}$ After that date the number of AFORES gradually started to increase again. In December 2005, there were 13 AFORES. The number of AFORES continued to increase in 2005 and 2006. By December 2007, the system had 21 AFORES.

García and Rodríguez (2003) find that there are economies of scale in the Mexican pension fund managers industry contributing to the decline in the number of AFORES. When there are economies of scale, larger pension fund managers will always have a comparative advantage over smaller ones. In this case market shares should be regulated to promote competition and allow lower coverage pension fund managers to develop. In a later study Aguilera and Velázquez (2005) find that most firms have crossed the minimum average cost of production and therefore no economies of scale exist in the Mexican case. The authors mention that part of this was achieved by the 2001 regulatory change assigning workers who had not chosen an AFORE to the pension fund with the lowest fees. This measure has allowed small pension fund managers to grow and consolidate in the market.

Table 3 shows the market share of some of the main AFORES. We observe that the market was more concentrated at the beginning of 1998. Banamex, Bancomer, and Profuturo GNP had more than 11\% of the market share. Bancomer had the highest share of the market (16.1\%). More than two years after the system started, by December 2001, market concentration stayed the same; Bancomer, Banamex, and Profuturo GNP had more than $10 \%$ of the market share. Diversification increased by 2004 but the main AFORES, Bancomer and Banamex maintained their leading position in the market. Bancomer and

\footnotetext{
${ }^{4}$ Mesa-Lago (2005) shows that the reduction in the number of pension fund mangers following their introduction has been observed in other countries as well. Some examples are Argentina moved from 25 to 12, Chile from 21 to 7, Colombia from 10 to 6, and Peru from 8 to 4.
} 
Banamex have been historically the banks with the highest coverage in Mexico. Bancomer has 1,341 branches all over Mexico and Banamex has 1,264.

In December 2007, Banamex and Bancomer have the highest market share, $15.3 \%$ and 11.5\%, respectively. All other AFORES have a market share below 10\%. Another AFORE with the highest coverage in terms of branches in Mexico is HSBC that merged with a Bank called “Bital”. The AFORE of HSBC started only in February 2004 and gained a market share of $4.7 \%$ by December 2007. The bank HSBC counts 1,446 branches in Mexico. Solida Banorte Generali has also wide coverage in Mexico with 946 branches. It is worth noting that Inbursa has $8.9 \%$ of the market but has only 64 branches to provide services. Also AFORE XXI, has $7.0 \%$ of the market share and 48 branches. ING has 67 branches. Inbursa, AFORE XXI, and ING have branches mainly in Mexico City and other main cities in Mexico. It seems that the market shares are more even in Mexico City but there is a higher concentration in Banamex and Bancomer because they capture workers in other towns outside Mexico City due to their wider coverage.

\subsection{PENSION FUND MANAGEMENT FEES AND PARTICIPANT SWITCHING BEHAVIOR}

The PRA system regulates the types of fees that financial institutions can charge. It has allowed three types of fees: load factor, fees charged on the account balance, and fees charged on the accrued interest. ${ }^{5}$ Other countries also allow fixed fees. Even though these types of fees are the most important source of revenue for pension fund managers, there are other fees for services such deposits and withdrawals from voluntary savings accounts allowing them to create the fee system that positions them best in the market. Such a fee system may or may not be related to the cost structure faced by the firm (Barrientos and Boussofiane, 2005) nor to the performance of the pension funds (Crabbe, 2005). For most countries however, fees are set as a percentage of contributions. Few countries set fixed fees - sometimes in addition to the percentage charged on contributions - and in other cases in addition to fees charged on the account balance (Crabbe, 2005).

Figure 2, Figure 3, and Figure 4 show the evolution of the load factor, balance, and interest fees, respectively, from 1998 to 2008. We observe changes over time in these fees.

\footnotetext{
${ }^{5}$ In the case of Chile, pension fund managers are allowed to either charge a fixed sum or a variable percentage on contributions (Mesa-Lago and Demesa, 2006).
} 
They are partly a result of changes in the regulatory framework mandating increased information and transparency.

Table 4 shows load factor fees by main pension fund managers. In May load factor fees were between $0.0 \%$ and $1.7 \%$ (see Figure 2 ). It is important to point out that the way load factor fees are quoted makes them appear very small when in fact they translate into very high fees. We will illustrate this with an example: take a worker who earns $\$ 1,000$. Total contributions amount to $6.5 \%$ of salary or $\$ 65$. A load factor fee of 1 percent is applied to the contributed amount divided by 6.5\%: (\$65/0.065) x $1 \%=\$ 10$. If the load factor were quoted as a percentage of the contribution, as is customary in the U.S., it would have to be quoted as 15.4 percent. A load factor of 1.5\% in the Mexican PRA system translates into a load factor of $23 \%$ in the U.S. context. The pension fund managers (AFORES) charging the lowest load factor fees in 1998, started increasing fees towards the end of 1998 and continued to do so until 2002. In December 1999, load factor fees for those AFORES charging them were between 1.35\% and 1.7\%, and in December 2002 they were between $1.45 \%$ and $1.7 \%$. By the end of 2002, load factor fees had a lower variance converging towards the highest fee charged in the market by Banamex (1.7\%).

Since December 2003, load factor fees started to decline (see Table 4). By December 2003, load factor fees were between $0.5 \%$ and $1.7 \%$. This decline was due to a change in the regulatory framework. AFORES had to send out PRA statements at least once a year. In October 2002, this changed to at least twice a year, and the statement had to provide information about employee contributions, and fees charged by the AFORE. Moreover, the switching mechanism between AFORES became more flexible. In December 2003, 2.4\% of the persons registered in the PRA system were switching between AFORES (see Figure 5).

Therefore, the decline in load factor fees may be due to a more detailed statement providing information about fees and prompting employees to switch more actively between pension fund managers in response to the information provided. Some AFORES do not charge a load factor fee. For example, Inbursa did not charge load factor or balance fees until December 2003. Before December 2003, Inbursa only charged a fee on the accrued interest of 33.0\% (see Table 4).

Between 2003 and 2005 load factor fees stayed relatively stable. Those AFORES that changed them only increased or decreased fees slightly (see Figure 2). Banamex had 
the highest load factor fee from 1998 to 2003 (1.70\%). Bancomer had the second highest load factor fee (1.68\%) from to 2003. Profuturo GNP started with a load factor fee of $1.70 \%$ that stayed in place until July 1999, then decreased to $1.64 \%$ by December 2006, and continued its decline down to $1.60 \%$ in December 2007.

AFORES with the highest market share had higher load factor fees (see Table 3). It is clear that a higher concentration of the market is not conducive to declining fees and enhancing competition. More transparency in the employee statement and detailed information of the system appears to have increased switching behavior and competition between AFORES. Individuals' switching behavior may depend on the fees charged by AFORES as well as on the tendency to move to those with the highest market share or those available in their home town.

From December 2006, load factor fees decreased more sharply. In December 2007, load factor fees were between $0.5 \%$ and $1.6 \%$. Banamex decreased the load factor fee to 0.75\%. Profuturo GNP and Confia Principal have the highest load factor fee (1.6\%). The main change in the regulatory framework in November 2005 was to include penalties for AFORES if they

- requested employees to switch the individual account without his or her consent,

- $\quad$ failed to disclose information about the individual account to the employee, or

- $\quad$ charged fees exceeding the allowed limits. ${ }^{6}$

The regulatory framework may have changed due to a large volume of complaints in 2005 about AFORES not complying with the regulation, charging fees incorrectly and not providing information about the individual account to workers. This also may have negatively affected customers' trust in the operations of the AFORES and AFORES may have responded by decreasing their fees. Moreover, the number of AFORES rose substantially since 2005, increasing market competition and causing part of the decline in fees during this period.

In Figure 5 we present the fraction of persons switching per month. We observe a sharp increase of switchers since October 2001. The Mexican regulation established that beginning in 2001, workers who did not choose a pension fund manager were assigned by

\footnotetext{
${ }^{6}$ Ley de los Sistemas de Ahorro para el Retiro, Article 100.
} 
the government to those AFORES with the highest return net of fees. ${ }^{7}$ Figure 1 shows the resulting 36\% increase in the number of persons registered in the PRA system in June 2001 reflecting the change in the regulatory framework.

The fraction of switchers in the PRA system has increased steadily, reaching 5.4\% of the total number of persons registered in January 2008, which amounts to more than two million switchers. Also the number of persons registered in the PRA system has increased significantly. In Figure 1, we observe that in May 1998, the PRA system had 12.4 million individual accounts. In December 2004, the number of individual retirement accounts increased to 31.4 million, and by December 2008, there were 38.5 million accounts.

Figure 3 shows the distribution of fees charged on account balances. In May 1998 balance fees were between $0.0 \%$ and $1.5 \%$. Solida Banorte Generali charged the highest balance fee. Since December 1999 balance fees started to decline, converging towards an average of $0.35 \%$ in December 2006. The AFORES charging the highest balance fees were Banamex (1.48\%), Bancomer (0.5\%), Inbursa (0.5\%) and Profuturo GNP (0.5\%). Many more AFORES started charging balance fees beginning in March 2003 and by February 2006 most AFORES charged a balance fee. Table 5 shows the balance fees for the main pension fund managers.

Figure 4 shows the market structure of fees charged on accrued interest. In May 1998 only two AFORES charged interest fees, Atlantico Promex (20\%) and Inbursa (33\%) (see Table 6). Atlantico Promex merged with Principal in November 1998. Inbursa was the only one charging an interest fee until March 2003.

Another factor playing a role in retaining workers in a particular pension fund is the provision of discounts on fees due to tenure with the fund. The first AFORES to implement such discount schemes included Banamex and Bancomer. These discounts consisted of decreasing load factor fees by $0.01 \%$ or $0.02 \%$ or $0.05 \%$ per year after being with the same fund between two to five years. By the year 2006 most AFORES had adopted discount schemes to increase customer loyalty by making switching more costly. Some AFORES completely eliminate the load factor fee after 25 years of tenure. As a result switching between pension funds managers is less desirable because that causes a loss in tenure and the associated fees discounts.

\footnotetext{
${ }^{7}$ Ley de los Sistemas de Ahorro para el Retiro, Article 76.
} 
In Table 7 we show the rules of discounts valid from 1998 to 2007 for Banamex, Bancomer, Profuturo GNP, and Inbursa pension fund managers. This table includes two of the pension fund managers (Banamex, and Bancomer) with the highest market share. Profuturo GNP had a high market share in 1998, comparable to Banamex and Bancomer, but coverage declined substantially by 2007. We include Inbursa, a pension fund with a low market share in 1998 which caught up reaching coverage just below the two biggest pension funds but above Profuturo GNP by 2007. We observe in Table 7 that Profuturo GNP only started granting discounts in November 2002, five years after the PRA system started. Profuturo GNP has a more generous discount system than any other pension fund and still this AFORE was less successful at retaining registered individuals and attracting new participants.

Summarizing patterns of retention and attracting individuals registered in other pension funds, Table 8 shows the net number of switchers for selected pension funds. Banamex has a successful history of attracting individuals from other pension funds in excess of the number of participants leaving Banamex (see Tables 9 and 10). Bancomer from 2003 to 2006 had difficulties retaining enrollees. Inbursa has had a history of losing more persons than gaining individuals switching from other AFORES. Profuturo GNP since 2002 has been successful both in retaining and attracting individuals. Table 9 shows the leavers by main pension fund managers and Table 10 shows individuals that moved from other pension fund managers. We find that the dynamics of attracting new system participants can be quite different from those of individuals switching between pension funds. The increase in the market share of Inbursa is mainly due to new entries to the system but is has a poorer performance in terms of retention and attracting persons registered in other pension funds.

There are many factors that influence individuals' choice of pension fund manager such as the number of branches, fees, discounts for tenure as well as aspects related to the company’s sales strategy. Calderón, Domínguez and Schwartz (2008) find for the Mexican case switching behavior responds more to sales strategies of AFORES than to price competition in the period from 1997 to 2006. Calderón, Domínguez and Schwartz calculate that resulting from uninformed individuals switching pension funds, 52.8\% of transfers in 2006 resulted in lower pensions. Marketing is assumed to be an important determinant in the early stages of a new system which fades later on when individuals learn more about 
the rules and are closer to retirement age. Whether this is also true for the Mexican case would be interesting to investigate. For example, one might compare the switching behavior of younger cohorts with that of older cohorts. Similarly, one might compare the choices of younger new entrants to those of older new entrants.

\subsection{RATES OF RETURN AND PORTFOLIO COMPOSITION}

The investment portfolio of AFORES is highly regulated. At the time when the PRA system was introduced, there was only one authorized investment portfolio that mandated that most of the funds had to be invested in government bonds. Table 11 shows that in December 2000, government bonds represented 96\% of the investment portfolio of AFORES. Investment in international financial instruments was not allowed until April 2005. Table 11 shows that since their introduction the proportion of government bonds in the investment portfolios has decreased and the proportion of non-government and international instruments has increased. Nevertheless, in December 2007, 69\% of the portfolios of AFORES were still invested in government bonds.

In 2004, there were two authorized investment portfolios (Siefore Básica 1 and Siefore Básica 2). Siefore Básica 1 mainly prescribed investment in risk free assets designed for individuals close to retirement age and Siefore Básica 2 allowed investment in riskier financial instruments with higher expected returns designed for younger cohorts. Since 2008, the number of authorized investment portfolios has risen to 5 intended to offer suitable investment options for different age groups. Siefore Básica 1 is for individuals age 56 or older, Siefore Básica 2 for individuals between age 46 and 55, Siefore Básica 3 for persons between 37 and 45 years old, Siefore Básica 4 includes those between 27 and 36 years old, and Siefore Básica 5 is for persons up to age 26. The investment returns are least risky for Siefore Básica 1 and most risky for Siefore Básica 5. All investment portfolios allow foreign instruments. Individuals cannot choose between Siefores unless they want to decrease the risk of the investment portfolio. Chile has also five investment portfolios with different levels of risk but the concentration of government bonds was only 7.8\% in December 2007 (AIOS, 2007).

In Figure 6, we present the real rate of return of AFORES for Siefore Básica 1 from 1998 to 2007 without adjusting for fees. For every month we show the median, highest and lowest rate of return and include for comparison a line for the real rate of return of the 
Mexican Treasury Bills, CETES. Table 12 shows the associated real rates of return before fees by main pension funds. We find that between 1998 and 2005 the highest, median and lowest values are not all that different from each other. Also, there is very little difference

in fund performance by pension fund manager (Table 12). The average real rate of return is 7.3\% and the standard deviation is 0.63 . From December 2006, we observe an increased variability in the real rates of return . The average real rate of return from December 2006 to December 2007 is $6.6 \%$ and the standard deviation is 1.30 .

Comparing the real rate of return of the AFORES with that of the leading Mexican Treasury Bills, CETES, in Figure 6 we note that from 1998 to 2003 there appears to be amazingly little correlation between the two; in fact, they appear to move in opposite directions much of the time. This is surprising because during that period the authorized portfolio mandated an investment share in government bonds of more than 95 percent. This may be due to the composition of government bonds held by the AFORES, possibly being heavily concentrated in indexed-linked bonds government bonds. We have not yet been able to confirm this. Since 2003, the real rate of return of CETES and the AFORES follow the same trends and are quite comparable.

As mentioned before another investment portfolio was authorized in 2004: the Siefore Básica 2, with riskier returns than those associated with Siefore Básica 1. In Figure 7 we show the real rate of return of Siefore Básica 1 and Siefore Básica 2 in comparison from 2004 to 2007. Table 13 shows the corresponding real rates of return for Siefore Básica 2 by main pension fund. The median real rate of return of Siefore Básica 1 and Siefore Básica 2 follow the same trend in 2004. From 2004 onwards there is a higher variability in the median and the highest real rate of return of Siefore Básica 2. Note that the minimum real rate of return is very similar in both investment portfolios. The standard deviation for Siefore Básica 2 is 1.25 and for Siefore Básica 1 it is 1.00.

\section{IMPACT OF FEES ON PRA SOCIAL SECURITY BENEFITS}

In this section we analyze the impact of pension fund management fees on PRA social security benefits. As described in the previous section, pension fund management fees have undergone drastic changes from 1997 to 2007. We assess the importance of the different types of fees for the accumulation of pension funds for a median worker. A 
median worker earns three times the minimum wage that is equivalent to $\$ 345$ dollars per month. The monthly minimum wage in Mexico City is \$115 dollars.

We assume a real rate of return of pension funds before fees of $5.44 \%$, which is a historic average. The monthly contribution to the PRA is equivalent to $6.5 \%$ of a worker's wage including employer, employee, and government contribution. Additionally, the government deposits the social quota amounting to $\$ 6.3$ per month. We assume the median worker starts contributing to the PRA system in May 1998, when we start observing pension fund management fees. Load factor fees are charged as a fraction of the worker's salary and balance fees are charged annually.

We estimate the amount accumulated in the PRA system for a median worker in each pension fund. We apply the exact fee schedule for each pension fund manager taking into account all the different types of fees, including discounts. The baseline scenario assumes no fees are charged. We compute the loss due to fees for each pension fund expressed in percent of the balance that would have accumulated without fees. That is every period we take the difference between the accumulation in a particular pension fund with fees and without fees, and divide by the scenario without fees. Changes in the slope of the loss in pension funds reflect changes in fees.

In Figure 8 we show the loss on pension balances due to load factor fees for a median worker. For balances with several AFORES the loss amounts to as much as 20 percent due to this load factor alone. We observe that the loss has not changed for most pension funds and for some it has even increased. This is the case for Sólida Banorte Generali and Confía Principal, for example. Even though we observed a decline in load factor fees in Figure 2 this translates into a constant or slightly increasing loss at decreasing rates over time. The median loss was $19.2 \%$ in May 1998. The minimum load factor fee loss is around zero because Inbursa only charged an interest fee but started charging a load factor fee in June 2003. The highest load factor fee loss pertains to Banamex, Bancomer, ING, and Profuturo GNP. Banamex and Bancomer have been consistently AFORES with the highest market share. This may indicate that many individuals are not aware of the impact of load factor fees on their accumulations and therefore fail to consider these in their decision to join or switch to a particular pension fund. The standard deviation of the loss due to load factor fees is 5.4 in January 2008. 
Figure 9 shows the losses in pension accumulations due to fees charged on the account balance. They are small initially, but increasing over time. The rate of increase is somewhat smaller between 2002 and 2005. There is substantial heterogeneity across pension funds in the loss resulting from balance fees. The minimum balance fee is around zero as Banamex, Bancomer, HSBC, and Inbursa only started charging this fee after 2003. The highest balance fee pertains to Sólida Banorte Generali. In December 1998, the standard deviation was 0.56 but it declines to 0.25 in October 1999.

The loss in pension accumulations as a result of interest fees is noticeable, even though far short of the losses due to load factor fees (see Figure 10). Only two pension funds charged interest fees: Inbursa and Atlántico Promex. The latter merged with Confía Principal in November 1998. Inbursa charged an interest fee from 1998 until May 2003. The interest fee for Inbursa was 33.0\%. We observe in Figure 10 a loss of $0.1 \%$ of pension accumulations in May 1998 for a median worker registered with Inbursa, but this loss reaches 4.5\% in May 2003. It declines slowly after May 2003 because Inbursa stopped charging this type of fee.

Figure 11 shows the loss in pension accumulations due to load factor fees taking into account discounts for tenure. Discounts start from two years of tenure in Bancomer and from five years of tenure in most other AFORES. The savings resulting from these discounted fees are very small reducing the loss by $0.15 \%$ on average in December 2007. It follows that they have practically no impact on the real incentives to stay with a particular pension fund. The highest discounts for tenure in December 2007 are granted by Bancomer and Profuturo GNP. Bancomer's discount for tenure reduces the loss in pension accumulations by $0.39 \%$; the corresponding figure for Profuturo GNP is $0.40 \%$. Even though the real impact of fee discounts is negligible AFORES may still have been able to use them as a marketing tool to influence participants' choices.

Discounts may play a more important role in the future. Since 2007, they have contributed to declining load factor fees in an important way. Before 2007, discounts reduced load factor fees to a minimum rate of approximately 1\%, while after 2007 load factor fees could be reduced to about $0.50 \%$ or lower in most AFORES when taking into account discounts for tenure.

In Figure 12 we show the loss in pension accumulations due to all types of fees combined (load factor, balance, and interest fee) for a median worker. In May 1998, the 
lowest loss in pension accumulations was $0.1 \%$ of the amount that would have been accumulated without fees. This fraction rises to 7.0\% in January 2008. The lowest loss is for a worker registered with Inbursa. The slope of the loss with Inbursa increases after the interest fee is eliminated and other fees were adopted.

The highest loss in pension accumulations affects clients of Profuturo GNP (23.2\% in January 2008). This is mainly due to the load factor fee. The second highest loss in accumulations would be experienced with Banamex. Confia Principal and ING occupy the third place in terms of loss of pension accumulations with 19.8\% in January 2008.

\section{Conclusions}

In this paper we document that fees as they have been charged by AFORES in the Mexican PRA system have a large impact on individuals’ pension accumulations, draining personal retirement accounts by up to almost a quarter of the amount that they would have accumulated without fees. Thus, it is extremely important to pay attention to the design of fees when designing PRA systems and when studying how such a reform might affect economic preparation for retirement. In the Mexican there are three different types of fees (load factor, balance and interest) that need to be taken into account. The greatest losses are due to the load factor, however.

To enhance transparency for individuals it would appear advisable restrict the types of fees to one common one to be used by all pension funds. Understanding the long-term consequences of just one type of fee is not a straightforward exercise for individuals.

Furthermore, for Latin American countries the structure of fees is generally not based on costs (Crabbe (2005) and Devesa et al. (2002)) with the implication that competition has not resulted in a rational system of fees. These findings are similar to Soto (2005) for the Chilean case who finds that more than a fifth of pension accumulations are lost due to management fees. Fees include administrative costs and competition costs, sales personnel, differentiation, and advertisement (Crabbe, 2005). This last element has led analysts to conclude that competition has not lead to reduced costs but instead to increased costs, eliminating economies of scale created by a large provider (Gill et al. 2008). In Chile other costs such as sales increased substantially during the 1990s since it proved to be the best strategy for firms to retain and increase market share (Barrientos, 2005). 
In future research, we will compare retirement benefits under the old pay-as-you-go and the new PRA system. We will assess the effects of fees on the different cohorts affected by the pension reform. 


\section{References}

Aguila, Emma, "Análisis Costo-Beneficio de la Inversión de las Reservas del Sistema de Pensiones del Instituto Mexicano del Seguro Social (1944-1994)," Instituto Tecnológico Autónomo de México (ITAM), Mimeo, 2000.

Aguila, Emma, Ximena Quintanilla, and Orazio Attanasio, "Cobertura del Sistema Privado de Capitalización”, Institute for Fiscal Studies (UCL), Mimeo," Institute for Fiscal Studies (UCL), Mimeo, 2008.

Aguila, Emma, "Personal Retirement Accounts and Saving," RAND Working Paper No. 600, 2008.

Aguilera, Nelly and Cesar Velázquez, "¿Economías de escala en la industria de las administradoras de fondos de pensiones? Un enfoque semiparamétrico," 2005.

Arenas de Mesa, Alberto and Carmelo Mesa-Lago, "The Structural Pension Reform in Chile: Effects, Comparisons with other Latin American Reforms, and Lessons," Oxford Review of Economic Policy, Vol. 22, No. 1, 2006, pp. 149-167.

Arenas de Mesa, Alberto, David Bravo, Jere Behrman, Olivia S. Mitchell, and Petra E. Todd, "The Chilean Pension Reform Turns 25: Lesson from the Social Protection Survey," NBER Working Paper No. 12401, 2006.

Barrientos, Armando and Aziz Boussofiane, "How Efficient are Pension Fund Managers in Chile?," Revista de Economia Contemporânea Vol. 9, No. 2, 2005, pp. 289-311.

Berstein, Solange and José Luis Ruiz, "Sensibilidad de la demanda con consumidores desinformados: el caso de las AFP en Chile," Revista de Temas Financieros, Vol. 1, No. 1, 2004.

Berstein, Solange and Carolina Cabrita Felix, "Deteriminants of AFP Demand in Chile: New Empirical Evidence from Individual Data," Estudios de Economía, Vol. 34, No. 1, June 2007, pp. 53-72.

Bolaños, Isalia Nava and Roberto Ham Chande, "Divididendos Demográficos y el Sistema de Pensiones de Retiro," Papeles de Población, Centro de Investigación y Estudios Avanzados de la Población UAEM No. 050, 2006.

Calderón-Colín, Roberto, Enrique E. Domínguez, and Moises J. Schwartz, "Consumer Confusion: The Choice of AFORE in Mexico," International Monetary Funds (IMF) Working Paper WP/08/177, July 2008.

Carpio, José Enrique Devesa, Rosa Rodríguez Barrera, and Carlos Vidal Meliá, "Los Costes de Administración para el Afiliado en los Sistemas de Pensiones Basados en Cuentas de Capitalización Individual: Medida y Comparación Internacional," Fundación de la Cajas de Ahorros Confederadas para la Investigación Económica y Social Documento de Trabajo No. 17, 2002.

Carpio, José Enrique Devesa, Mónica Martínez, and Carlos Vidal, "Análisis y Valoración de los Sistemas de Pensiones Reformados en Latinoamérica," Instituto Valenciano de Investigaciones Económicas Working Paper EC 2000-11, 2002.

Corbo, Vittorio, "Policy Challenges of Population Aging and Pension Systems in Latin America," Global Demographic Change: Economic Impacts and Policy Challenges. Federal Reserve Bank of Kansas City, 2004. 
Crabbe, Carolin A., ed. A Quarter Century of Pension Reform in Latin America and the Caribbean: Lessons Learned and Next Steps. Washington D.C.: Inter-American Development Bank, 2005.

Devesa, José Enrique., R. Rodríguez, and Carlos Vidal, "Los costes de administración para el afiliado en los sistemas de pensiones basados en cuentas de capitalización individual: Medida y comparación internacional," Fundación para la Investigación Económica y Social, 2002.

Estructura de Comisiones de Afore Argos S.A. de C.V., México, D.F, June 8, 2007.

Fischer, Ronald, Rodrigo Gutierrez, and Pablo Serra, "The Effects of Privatization on Firms and on Social Welfare: The Chilean Case," Inter-American Development Bank Latin American Research Network Research Network Working Paper No. R456, May 2003.

García, M. and T. Rodríguez, "La Organización del Mercado de Ahorro para el Retiro Mexicano Durante su Etapa de Acumulación," Instituto Tecnológico Autónomo de México (ITAM), Mimeo, 2003.

Gill, Indermit S., Truman Packard, Todd Pugatch, and Juan Yermo, "Rethinking social security in Latin America," International Sociological Review, Vol. 58, No. 2-3, 2005.

Gill, Indermit S., Ceren Ozer, and Radu Tatucu, "What Can Countries in Other Regions Learn from Social Security Reform in Latin America?," The World Bank Research Observer, Vol. 23, No. 1, 2008, p. 57.

Grandolini, Gloria and Luis Cerda, The 1997 Pension Reform in Mexico: Genesis and Design Features, April 22, 1998.

James, Estelle, James Smalhout, and Dimitri Vittas, "Administrative costs and the organization of individual account systems: a comparative perspective," Revista de Temas Financieros, 2001.

Kay, Stephen J. and Tapen Sinha, Lessons from Pension Reform in the Americas, New York: Oxford University Press, 2008.

Kritzer, Barbara E., "Social Security Privatization in Latin America," Social Security Bulletin, Vol. 63, No. 2, 2000, pp. 17-37.

Lazén, Vicente, "Competitividad de la Inducstria de Fondo Mutuos en Chile," Superintendencia de Valores y Seguros Chile, Documento de Trabajo No. 1, May 2004.

Madero, David S. and Antonio T. Mora, "Fomento a la Competencia entre las Administradoras de Fondos para el Retiro: Acciones y Resultados en México," 2006.

Mesa-Lago, Carmelo, "Reassessing Pension Reform in Chile and Other Countries in Latin America," 2002.

Mitchell, Olivia S., "Evaluating Administrative Costs in Mexico’s AFORES Pension System," Pension Research Council Working Paper 99-1, January 1999. 
Prieto, Salvador Valdés, "Para aumentar la competencia entre las AFP," Centro de Estudios Públicos, October 5, 2004.

Reyes, Gonzalo and Francisco Pino, "Income inequality in an Individual Capitalization Pension System: The case of Chile," April 2005.

Shah, Hemant C., "Toward Better Regulation of Private Pension Funds," World, 1997.

Soto, Mauricio, Chilean Pension Reform: The Good, the Bad, and the in Between: Center for Retirement Research, 2005.

World Bank, "Averting the Old Age Crisis: Policies to Protect the Old and Promote Growth," World Bank, 1994. 
Table 1-Number of persons registered to the PRA system by pension fund managers from 2000 to 2007

\begin{tabular}{|c|c|c|c|c|c|c|c|c|}
\hline AFORE & 2000 & 2001 & 2002 & 2003 & 2004 & 2005 & 2006 & 2007 \\
\hline Banamex & $2,248,343$ & $2,640,629$ & $5,269,868$ & $5,612,068$ & $5,822,157$ & $5,691,283$ & $5,596,232$ & $5,909,937$ \\
\hline $\begin{array}{l}\text { Bancomer } \\
\text { Confia }\end{array}$ & 2,868,189 & $3,740,168$ & $4,353,848$ & $4,328,805$ & 4,324,299 & $4,287,401$ & $4,255,568$ & 4,414,395 \\
\hline $\begin{array}{l}\text { Principal } \\
\text { Ahorra }\end{array}$ & 610,745 & $1,300,417$ & $2,198,895$ & $3,210,145$ & $3,227,762$ & $3,301,712$ & $3,326,545$ & $3,026,731$ \\
\hline Ahora & - & - & - & - & - & - & 155,942 & 377,994 \\
\hline Arg & - & - & - & - & - & - & - & 7,367 \\
\hline Copp & - & - & - & - & - & - & 203,834 & 358,770 \\
\hline Scotia & - & - & - & - & - & - & 673 & 14,055 \\
\hline Metlife & - & - & - & - & 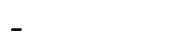 & 50,199 & 112,833 & 126,585 \\
\hline HSB & - & - & 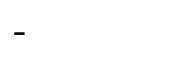 & - & 1,4 & $1,6 s$ & $1,767,775$ & 1,829,670 \\
\hline Inburs & 391,02 & 1,095 & 1,93 & 2,12 & & 3,25 & $3,630,280$ & $3,424,203$ \\
\hline ING & - & 2,720, & 2,708 & $2,692,066$ & $2,626,500$ & 2,42 & $2,314,651$ & $2,268,018$ \\
\hline $\begin{array}{l}\text { Azteca } \\
\text { Afirme }\end{array}$ & - & - & - & 446 & 821,973 & $1,206,945$ & $1,270,951$ & $1,134,693$ \\
\hline Bajio & - & - & - & & - & 71 & 422 & 752 \\
\hline ercap & - & - & - & - & - & 327 & 833,415 & 979,467 \\
\hline $\begin{array}{l}\text { IXE } \\
\text { Profuturo }\end{array}$ & - & - & 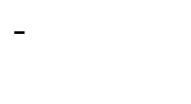 & - & 163 & 182,124 & 184,673 & 304,351 \\
\hline $\begin{array}{l}\text { GNP } \\
\text { Solida } \\
\text { Banorte }\end{array}$ & 2,098 & 2,783 & 2,92 & 3,1 & 3,36 & 3,4 & $3,403,090$ & $3,188,220$ \\
\hline Generali & 1,581, & 2,400 & 2,61 & 2,78 & 2,90 & $3,044,085$ & $3,282,539$ & $3,281,580$ \\
\hline XXI & 579,099 & $1,300,417$ & $1,982,478$ & $2,218,455$ & $2,212,863$ & $2,286,349$ & $2,402,682$ & $2,698,172$ \\
\hline
\end{tabular}

NOTE: All dates refer to the month of December. - Refers to AFORES created after July 1997: Ahorra Ahora (Sep-2006), Argos (Jan-2007), Coppel (Jan-2006), Scotia (Dec-2006), Metlife (Mar-2005), HSBC(Feb-2004), ING (Dec-2001), Azteca (Apr-2003), Afirme Bajio (Dec-2005), Invercap (Mar-2005), IXE (Jul-2004)

SOURCE: Comisión Nacional del Sistema de Ahorro para el Retiro (CONSAR). 
Table 2-Amount accumulated in the PRA system for mandatory and voluntary contributions

\begin{tabular}{lll}
\hline Date & $\begin{array}{l}\text { Amount accumulated in the PRA } \\
\text { system for mandatory } \\
\text { contributions (millions of } \\
\text { dollars) }\end{array}$ & $\begin{array}{l}\text { Amount accumulated in the } \\
\text { PRA system for voluntary } \\
\text { contributions (millions of } \\
\text { dollars) }\end{array}$ \\
\hline December 2000 & $15,880.62$ & 84.59 \\
December 2001 & $24,224.22$ & 151.38 \\
December 2002 & $31,532.24$ & 190.05 \\
December 2003 & $39,288.18$ & 222.12 \\
December 2004 & $46,914.58$ & 203.09 \\
December 2005 & $57,700.87$ & 198.14 \\
December 2006 & $71,221.18$ & 233.67 \\
December 2007 & $81,644.33$ & 265.11 \\
\hline
\end{tabular}

NOTE: The exchange rate used is $\$ 10.00$ pesos per dollar.

SOURCE: Comisión Nacional del Sistema de Ahorro para el Retiro (CONSAR).

Table 3- Market share by main pension fund managers from 2000 to 2007 (\%)

\begin{tabular}{|c|c|c|c|c|c|c|c|c|c|}
\hline AFORE & 2000 & & 2001 & 2002 & 2003 & 2004 & 2005 & 2006 & 2007 \\
\hline Banamex & & 12.6 & 10.0 & 17.9 & 17.9 & 17.5 & 16.1 & 15.0 & 15.3 \\
\hline Bancomer & 16.1 & & 14.1 & 14.8 & 13.8 & 13.0 & 12.2 & 11.4 & 11.5 \\
\hline Confia Principal & 3.4 & & 4.9 & 7.5 & 10.2 & 9.7 & 9.4 & 8.9 & 7.9 \\
\hline Ahorra Ahora & - & & - & - & - & - & - & 0.4 & 1.0 \\
\hline Argos & - & & - & - & - & - & - & - & 0.0 \\
\hline Coppel & - & & - & - & - & - & - & 0.5 & 0.9 \\
\hline Scotia & - & & - & - & - & - & - & 0.0 & 0.0 \\
\hline Metlife & - & & - & - & - & - & 0.1 & 0.3 & 0.3 \\
\hline HSBC & - & & - & - & - & 4.3 & 4.8 & 4.7 & 4.7 \\
\hline Inbursa & 2.2 & & 4.1 & 6.6 & 6.8 & 7.5 & 9.2 & 9.7 & 8.9 \\
\hline ING & - & & 10.3 & 9.2 & 8.6 & 7.9 & 6.9 & 6.2 & 5.9 \\
\hline Azteca & - & & - & - & 1.4 & 2.5 & 3.4 & 3.4 & 2.9 \\
\hline Afirme Bajio & - & & - & - & - & - & 0.0 & 1.1 & 2.0 \\
\hline Invercap & - & & - & - & - & - & 0.9 & 2.2 & 2.5 \\
\hline IXE & - & & - & - & - & 0.5 & 0.5 & 0.5 & 0.8 \\
\hline Profuturo GNP & 11.8 & & 10.5 & 9.9 & 9.9 & 10.1 & 9.8 & 9.1 & 8.3 \\
\hline Solida Banorte Generali & 8.9 & & 9.1 & 8.9 & 8.9 & 8.7 & 8.6 & 8.8 & 8.5 \\
\hline XXI & 3.2 & & 4.9 & 6.7 & 7.1 & 6.6 & 6.5 & 6.4 & 7.0 \\
\hline
\end{tabular}

NOTE: All dates refer to the month of December. - Refers to AFORES created after July 1997: Ahorra Ahora (Sep-2006), Argos (Jan-2007), Coppel (Jan-2006), Scotia (Dec-2006), Metlife (Mar-2005), HSBC (Feb-2004), ING (Dec-2001), Azteca (Apr-2003), Afirme Bajio (Dec-2005), Invercap (Mar-2005), IXE (Jul2004). Percentages do not add up to $100 \%$ because we did not include AFORES that merged to other pension fund managers through this period.

SOURCE: Comisión Nacional del Sistema de Ahorro para el Retiro (CONSAR). 
Table 4— Load factor fees by main pension fund managers from 2000 to 2007 (\%)

\begin{tabular}{lllllllll}
\hline AFORE & 2000 & 2001 & 2002 & 2003 & 2004 & 2005 & 2006 & 2007 \\
\hline Banamex & 1.70 & 1.70 & 1.70 & 1.70 & 1.70 & 1.70 & 0.75 & 0.75 \\
Bancomer & 1.68 & 1.68 & 1.68 & 1.68 & 1.68 & 1.68 & 1.20 & 1.20 \\
Confia Principal & 1.60 & 1.60 & 1.60 & 1.60 & 1.60 & 1.60 & 1.60 & 1.60 \\
Ahorra Ahora & - & - & - & - & - & - & 0.90 & 0.70 \\
Argos & - & - & - & - & - & - & - & 0.97 \\
Coppel & - & - & - & - & - & - & 0.92 & 0.92 \\
Scotia & - & - & - & - & - & - & 1.22 & 1.22 \\
Metlife & - & - & - & - & - & 1.23 & 1.23 & 1.20 \\
HSBC & - & - & - & - & 1.60 & 1.42 & 1.40 & 0.75 \\
Inbursa & 0.00 & 0.00 & 0.00 & 0.50 & 0.50 & 0.50 & 0.50 & 0.50 \\
ING & - & 1.68 & 1.68 & 1.68 & 1.68 & 1.68 & 1.32 & 0.70 \\
Azteca & - & - & - & 1.10 & 1.10 & 1.10 & 0.90 & 0.90 \\
Afirme Bajio & - & - & - & - & - & 0.62 & 0.62 & 0.62 \\
Invercap & - & - & - & - & - & 1.03 & 1.03 & 0.80 \\
IXE & - & - & - & - & 1.10 & 1.10 & 1.10 & 0.76 \\
Profuturo GNP & 1.67 & 1.67 & 1.67 & 1.67 & 1.67 & 1.67 & 1.64 & 1.60 \\
Solida Banorte Generali & 1.45 & 1.45 & 1.45 & 1.40 & 1.40 & 1.40 & 1.25 & 0.70 \\
XXI & 1.45 & 1.45 & 1.45 & 1.30 & 1.30 & 1.30 & 1.30 & 0.60 \\
\hline
\end{tabular}

NOTE: All dates refer to the month of December. - Refers to AFORES created after July 1997: Ahorra Ahora (Sep-2006), Argos (Jan-2007), Coppel (Jan-2006), Scotia (Dec-2006), Metlife (Mar-2005), HSBC (Feb-2004), ING (Dec-2001), Azteca (Apr-2003), Afirme Bajio (Dec-2005), Invercap (Mar2005), IXE (Jul-2004). Load factor fees are computed as a percentage of worker's wage.

SOURCE: Comisión Nacional del Sistema de Ahorro para el Retiro (CONSAR). 
Table 5- Balance fees by main pension fund managers from 2000 to 2007 (\%)

\begin{tabular}{lllllllll}
\hline AFORE & 2000 & 2001 & 2002 & 2003 & 2004 & 2005 & 2006 & 2007 \\
\hline Banamex & 0.00 & 0.00 & 0.00 & 0.00 & 0.00 & 0.00 & 1.48 & 1.48 \\
Bancomer & 0.00 & 0.00 & 0.00 & 0.00 & 0.00 & 0.00 & 0.50 & 0.50 \\
Confia Principal & 0.45 & 0.45 & 0.45 & 0.45 & 0.45 & 0.35 & 0.35 & 0.35 \\
Ahorra Ahora & - & - & - & - & - & - & 0.20 & 0.20 \\
Argos & - & - & - & - & - & - & - & 0.12 \\
Coppel & - & - & - & - & - & - & 0.30 & 0.30 \\
Scotia & - & - & - & - & - & - & 0.26 & 0.26 \\
Metlife & - & - & - & - & - & 0.25 & 0.25 & 0.71 \\
HSBC & - & - & - & - & 0.40 & 0.40 & 0.40 & 1.20 \\
Inbursa & 0.00 & 0.00 & 0.00 & 0.50 & 0.50 & 0.50 & 0.50 & 0.50 \\
ING & - & 0.00 & 0.00 & 0.00 & 0.00 & 0.00 & 0.30 & 1.45 \\
Azteca & - & - & - & 0.15 & 0.15 & 0.15 & 0.40 & 0.40 \\
Afirme Bajio & - & - & - & - & - & 0.25 & 0.24 & 0.23 \\
Invercap & - & - & - & - & - & 0.20 & 0.20 & 0.36 \\
IXE & - & - & - & - & 0.35 & 0.34 & 0.33 & 0.25 \\
Profuturo GNP & 0.70 & 0.70 & 0.70 & 0.70 & 0.66 & 0.50 & 0.50 & 1.20 \\
Solida Banorte Generali & 1.00 & 1.00 & 1.00 & 0.70 & 0.60 & 0.50 & 0.40 & 1.14 \\
XXI & 0.20 & 0.20 & 0.20 & 0.20 & 0.20 & 0.20 & 0.20 & 1.50 \\
\hline
\end{tabular}

NOTE: All dates refer to the month of December. . - Refers to AFORES created after July 1997:

Ahorra Ahora (Sep-2006), Argos (Jan-2007), Coppel (Jan-2006), Scotia (Dec-2006), Metlife (Mar-2005), HSBC (Feb-2004), ING (Dec-2001), Azteca (Apr-2003), Afirme Bajio (Dec-2005), Invercap (Mar-2005), IXE (Jul-2004). Balance fees are an annual percentage.

SOURCE: Comisión Nacional del Sistema de Ahorro para el Retiro (CONSAR). 
Table 6 - Interest fees by main pension fund managers from 2000 to 2007 (\%)

\begin{tabular}{lllllllll}
\hline AFORE & 2000 & 2001 & 2002 & 2003 & 2004 & 2005 & 2006 & 2007 \\
\hline Banamex & 0.00 & 0.00 & 0.00 & 0.00 & 0.00 & 0.00 & 0.00 & 0.00 \\
Bancomer & 0.00 & 0.00 & 0.00 & 0.00 & 0.00 & 0.00 & 0.00 & 0.00 \\
Confia Principal & 0.00 & 0.00 & 0.00 & 0.00 & 0.00 & 0.00 & 0.00 & 0.00 \\
Ahorra Ahora & - & - & - & - & - & - & 0.00 & 0.00 \\
Argos & - & - & - & - & - & - & - & 0.00 \\
Coppel & - & - & - & - & - & - & 0.00 & 0.00 \\
Scotia & - & - & - & - & - & - & 0.00 & 0.00 \\
Metlife & - & - & - & - & - & 0.00 & 0.00 & 0.00 \\
HSBC & - & - & - & - & 0.00 & 0.00 & 0.00 & 0.00 \\
Inbursa & 33.00 & 33.00 & 33.00 & 0.00 & 0.00 & 0.00 & 0.00 & 0.00 \\
ING & - & 0.00 & 0.00 & 0.00 & 0.00 & 0.00 & 0.00 & 0.00 \\
Azteca & - & - & - & 0.00 & 0.00 & 0.00 & 0.00 & 0.00 \\
Afirme Bajio & - & - & - & - & - & 0.00 & 0.00 & 0.00 \\
Invercap & - & - & - & - & - & 0.00 & 0.00 & 0.00 \\
IXE & - & - & - & - & 0.00 & 0.00 & 0.00 & 0.00 \\
Profuturo GNP & 0.00 & 0.00 & 0.00 & 0.00 & 0.00 & 0.00 & 0.00 & 0.00 \\
Solida Banorte & & & & & & & & \\
Generali & 0.00 & 0.00 & 0.00 & 0.00 & 0.00 & 0.00 & 0.00 & 0.00 \\
XXI & 0.00 & 0.00 & 0.00 & 0.00 & 0.00 & 0.00 & 0.00 & 0.00 \\
\hline
\end{tabular}

NOTE: All dates refer to the month of December. - Refers to AFORES created after July 1997: Ahorra Ahora (Sep-2006), Argos (Jan-2007), Coppel (Jan-2006), Scotia (Dec-2006), Metlife (Mar-2005), HSBC (Feb-2004), ING (Dec-2001), Azteca (Apr-2003), Afirme Bajio (Dec-2005), Invercap (Mar-2005), IXE (Jul-2004).

SOURCE: Comisión Nacional del Sistema de Ahorro para el Retiro (CONSAR). 
Table 7-Discounts for selected pension fund managers from 1998 to 2007

\begin{tabular}{|c|c|c|c|}
\hline Banamex & Bancomer & Profuturo GNP & Inbursa \\
\hline $\begin{array}{l}\text { From the } 5^{\text {th }} \text { year of tenure, } \\
\text { the load factor fee will be } \\
\text { discounted } 0.02 \% \text { per year } \\
\text { (valid up to September } 2001 \text { ) }\end{array}$ & $\begin{array}{l}\text { From the } 2^{\text {nd }} \text { year up to the } \\
6 \text { th of tenure, the load factor } \\
\text { fee will be discounted } \\
0.01 \% \text { (valid up to May } \\
1998 \text { ) }\end{array}$ & --- & --- \\
\hline $\begin{array}{l}\text { From the } 5^{\text {th }} \text { year of tenure, } \\
\text { the load factor fee will be }\end{array}$ & $\begin{array}{l}\text { From the } 2 \text { nd year of tenure, } \\
\text { the load factor fee will be }\end{array}$ & $\begin{array}{l}\text { Started making discounts in } \\
\text { November } 2002 \text {. }\end{array}$ & $\begin{array}{l}\text { Started making discounts in June } \\
2003 .\end{array}$ \\
\hline $\begin{array}{l}\text { discounted } 0.02 \% \text { per year up } \\
\text { to a max of } 0.70 \% \text { (valid up to } \\
\text { December } 2005 \text { ) }\end{array}$ & $\begin{array}{l}\text { discounted } 0.01 \% \text { per year } \\
\text { up to a max } 0.05 \% \text { (valid up } \\
\text { to September } 2006 \text { ) }\end{array}$ & $\begin{array}{l}\text { From } 2003 \text {, after having } 5 \text { years of } \\
\text { tenure, the load factor fee decreases } \\
\text { by } 0.04 \% \text { per year up to a max of } 10 \\
\text { years (valid up to December } 2004 \text { ) }\end{array}$ & $\begin{array}{l}\text { After } 18 \text { years of tenure the load } \\
\text { factor fee is eliminated (valid up to } \\
\text { December 2008) }\end{array}$ \\
\hline $\begin{array}{l}\text { No changes, applies previous } \\
\text { one. }\end{array}$ & $\begin{array}{l}\text { No changes, applies previous } \\
\text { one. }\end{array}$ & $\begin{array}{l}\text { After having } 5 \text { years of tenure, the } \\
\text { load factor fee decreases by } 0.04 \% \\
\text { per year up to a max of } 10 \text { years. } \\
\text { After the } 15^{\text {th }} \text { year of tenure, load } \\
\text { factor fee declines } 0.05 \% \text { until } \\
\text { reaching } 24 \text { years of tenure. In the } \\
25^{\text {th }} \text { year the fee declines } \\
0.07 \% \text { (valid up to May } 2005)\end{array}$ & No changes, applies previous one. \\
\hline $\begin{array}{l}\text { No changes, applies previous } \\
\text { one. }\end{array}$ & $\begin{array}{l}\text { No changes, applies previous } \\
\text { one. }\end{array}$ & $\begin{array}{l}\text { After having } 5 \text { years of tenure, the } \\
\text { load factor fee decreases by } 0.50 \% \text {. } \\
\text { After the } 10 \text { th year of tenure, load } \\
\text { factor fee declines } 0.04 \% \text { per year } \\
\text { until the } 15 \text { th year of tenure. In the } \\
\text { 16th year of tenure the load factor } \\
\text { fee declines } 0.04 \% \text { per year until } \\
24 \text { th year of tenure. In the } 25 \text { th year } \\
\text { the fee declines } 0.07 \% \text { (valid up to } \\
\text { August } 2005 \text { ) }\end{array}$ & No changes, applies previous one. \\
\hline
\end{tabular}


Cont. Table 7-Discounts for selected pension fund managers from 1998 to 2007

\begin{tabular}{|c|c|c|c|}
\hline Banamex & Bancomer & Profuturo GNP & Inbursa \\
\hline $\begin{array}{l}\text { At the } 4^{\text {th }} \text { year of tenure, the } \\
\text { load factor fee is discounted } \\
0.04 \% \text {, from the } 5^{\text {th }} \text { to the } 8^{\text {th }} \\
\text { year of tenure, } 0.02 \% \text { discount } \\
\text { per year, from } 9^{\text {th }} \text { to the } 11^{\text {th }} \text {, } \\
\text { an annual discount of } 0.05 \% \text {, } \\
\text { a discount in the } 12^{\text {th }} \text { year of } \\
\text { tenure by } 0.10 \% \text {, from the } 14^{\text {th }} \\
\text { year of tenure, there is an } \\
\text { annual average discount of } \\
0.08 \% \text { until there is no load } \\
\text { factor fee charged from the } \\
26^{\text {th }} \text { year of tenure (valid up to } \\
\text { October } 2006 \text { ) }\end{array}$ & $\begin{array}{l}\text { No changes, applies previous } \\
\text { one. }\end{array}$ & $\begin{array}{l}\text { After having } 5 \text { years oftenure, the } \\
\text { load factor fee decreases by } 0.30 \% \text {. } \\
\text { In the } 12^{\text {th }} \text { year of tenure, load factor } \\
\text { fee declines by } 0.02 \% \text {. In the } 13^{\text {th }} \\
\text { and } 14^{\text {th }} \text { year of tenure the fee } \\
\text { declines by } 0.04 \% \text { per year. From } \\
\text { the } 15^{\text {th }} \text { year of tenure the load factor } \\
\text { fee declines } 0.04 \% \text { per year until } \\
24 \text { th year of tenure. In the } 25^{\text {th }} \text { year } \\
\text { the fee declines } 0.07 \% \text { (valid up to } \\
\text { December } 2006)\end{array}$ & No changes, applies previous one. \\
\hline
\end{tabular}


In the $5^{\text {th }}$ year of tenure, the load factor fee will be discounted $0.30 \%$, and in the sixth the fee declines $0.20 \%$. In the $11^{\text {th }}$ year of tenure, the load factor fee declines 0.05\% (valid up to December 2008)
No changes, applies previous one.
After having 5 years of tenure, the load factor fee decreases by $0.47 \%$. In the $17^{\text {th }}$ up to $23^{\text {rd }}$ year of tenure the fee declines by $0.05 \%$ per year. From the $24^{\text {th }}$ year of tenure the load factor fee declines $0.07 \%$ (valid up to December 2007)

\section{Cont. Table 7-Discounts for selected pension fund managers from 1998 to 2007}

\begin{tabular}{|c|c|c|c|}
\hline Banamex & Bancomer & Profuturo GNP & Inbursa \\
\hline $\begin{array}{l}\text { No changes, applies previous } \\
\text { one. }\end{array}$ & $\begin{array}{l}\text { From the 5th year of tenure, } \\
\text { the load factor fee will be } \\
\text { discounted } 0.485 \% \text {. This } \\
\text { change applies between } 2006 \\
\text { and } 2014 \text { (valid up to } \\
\text { December 2008) }\end{array}$ & $\begin{array}{l}\text { After having } 1 \text { year of tenure, the } \\
\text { load factor fee decreases by } 0.05 \% \text {, } \\
\text { in the second year } 0.6 \% \text {, in the third } \\
\text { year } 0.07 \% \text {, in the fourth year } \\
0.03 \% \text {, in the fifth year } 0.83 \% \text {, in } \\
\text { the sixth year } 0.08 \% \text {, in the seventh } \\
\text { year } 0.10 \% \text {, in the eight year } 0.12 \% \text {, } \\
\text { in the ninth year } 0.10 \% \text {, and in the } \\
\text { tenth year the load factor fee is } \\
\text { eliminated (valid up to December } \\
2008 \text { ) }\end{array}$ & No changes, applies previous one. \\
\hline
\end{tabular}

SOURCE: Comisión Nacional del Sistema de Ahorro para el Retiro (CONSAR). 
Table 8—Net number of switchers by main pension fund managers from 2000 to 2007

\begin{tabular}{lllllllll}
\hline AFORE & 2000 & 2001 & 2002 & 2003 & 2004 & 2005 & 2006 & 2007 \\
\hline Banamex & 7,632 & 78,576 & 254,208 & 376,879 & 430,885 & 263,678 & 145,302 & 396,704 \\
Bancomer & 4,616 & 15,294 & 26,123 & $-9,427$ & $-27,249$ & $-78,249$ & $-131,990$ & 60,475 \\
Confia Principal & $-1,911$ & $-22,988$ & $-95,114$ & $-170,516$ & $-198,007$ & $-213,424$ & $-285,431$ & $-439,016$ \\
Ahorra Ahora & - & - & - & - & - & - & -68 & $-7,699$ \\
Argos & - & - & - & - & - & - & - & 7,125 \\
Coppel & - & - & - & - & - & - & 23,250 & 131,920 \\
Scotia & - & - & - & - & - & - & 672 & 13,131 \\
Metlife & - & - & - & - & - & 49,766 & 111,391 & 123,969 \\
HSBC & - & - & - & - & 95,961 & 342,144 & 385,208 & 379,180 \\
Inbursa & 1,161 & $-29,721$ & $-131,821$ & $-228,223$ & $-278,795$ & $-85,501$ & 32,251 & $-156,304$ \\
ING & - & $-10,803$ & $-35,076$ & $-52,327$ & $-118,975$ & $-319,642$ & $-448,446$ & $-521,561$ \\
Azteca & - & - & - & $-21,181$ & $-78,574$ & $-14,097$ & 46,369 & $-126,723$ \\
Afirme Bajio & - & - & - & - & - & 71 & 25,886 & 2,228 \\
Invercap & - & - & - & - & - & 43,577 & 179,625 & 319,932 \\
IXE & - & - & - & - & $-5,721$ & $-25,301$ & $-23,782$ & $-12,495$ \\
Profuturo GNP & $-9,220$ & $-18,688$ & 55,883 & 218,365 & 405,693 & 429,081 & 366,297 & 281,202 \\
Solida Banorte Generali & 82 & 7,579 & 69,715 & 142,894 & 181,295 & 249,192 & 378,555 & 296,566 \\
XXI & 3,517 & $-7,150$ & $-60,901$ & $-155,220$ & $-240,924$ & $-303,279$ & $-362,912$ & $-369,763$ \\
\hline
\end{tabular}

NOTE: All dates refer to the month of December. The numbers in the cells are accumulated from the previous 12 months. - Refers to AFORES created after July 1997: Ahorra Ahora (Sep-2006), Argos (Jan-2007), Coppel (Jan-2006), Scotia (Dec-2006), Metlife (Mar2005), HSBC (Feb-2004), ING (Dec-2001), Azteca (Apr-2003), Afirme Bajio (Dec-2005), Invercap (Mar-2005), IXE (Jul-2004).

SOURCE: Comisión Nacional del Sistema de Ahorro para el Retiro (CONSAR). 
Table 9-Leavers by main pension fund managers from 2000 to 2007

\begin{tabular}{lllllllll}
\hline AFORE & 2000 & 2001 & 2002 & 2003 & 2004 & 2005 & 2006 & 2007 \\
\hline Banamex & 10,588 & 19,995 & 76,435 & 158,166 & 381,353 & 847,546 & $1,471,159$ & $1,934,706$ \\
Bancomer & 19,292 & 66,084 & 159,605 & 291,502 & 501,662 & 883,448 & $1,456,443$ & $1,878,266$ \\
Confia Principal & 3,650 & 32,722 & 152,243 & 340,002 & 488,290 & 733,780 & $1,134,954$ & $1,439,710$ \\
Ahorra Ahora & - & - & - & - & - & - & 138 & 7,880 \\
Argos & - & - & - & - & - & - & - & 892 \\
Coppel & - & - & - & - & - & - & 1,374 & 23,329 \\
Scotia & - & - & - & - & - & - & 0 & 2,132 \\
Metlife & - & - & - & - & - & 2,192 & 33,984 & 97,676 \\
HSBC & - & - & - & - & 210,764 & 334,914 & 615,039 & 830,514 \\
Inbursa & 2,325 & 37,065 & 153,525 & 322,985 & 535,982 & 737,361 & $1,040,791$ & $1,456,884$ \\
ING & - & 53,199 & 116,034 & 223,299 & 429,427 & 738,187 & $1,090,028$ & $1,379,738$ \\
Azteca & - & - & - & 37,295 & 149,652 & 256,906 & 453,357 & 657,765 \\
Afirme Bajio & - & - & - & - & - & 0 & 137 & 33,958 \\
Invercap & - & - & - & - & - & 5,883 & 52,279 & 191,766 \\
IXE & - & - & - & - & 9,632 & 42,986 & 70,520 & 94,947 \\
Profuturo GNP & 23,998 & 68,674 & 123,328 & 196,320 & 367,388 & 747,561 & $1,288,957$ & $1,773,707$ \\
Solida Banorte Generali & 9,853 & 43,602 & 86,350 & 132,486 & 252,642 & 487,897 & 872,322 & $1,263,419$ \\
XXI & 790 & 30,933 & 127,127 & 283,368 & 440,357 & 591,444 & 793,887 & 973,901 \\
\hline
\end{tabular}

NOTE: All dates refer to the month of December. The numbers in the cells are accumulated from the previous 12 months. Refers to AFORES created after July 1997: Ahorra Ahora (Sep-2006), Argos (Jan-2007), Coppel (Jan-2006), Scotia (Dec-2006), Metlife (Mar-2005), HSBC (Feb-2004), ING (Dec-2001), Azteca (Apr-2003), Afirme Bajio (Dec-2005), Invercap (Mar-2005), IXE (Jul-2004).

SOURCE: Comisión Nacional del Sistema de Ahorro para el Retiro (CONSAR). 
Table 10 - Individuals that moved from another AFORE by main pension fund managers from 2000 to 2007

\begin{tabular}{lllllllll}
\hline AFORE & 2000 & 2001 & 2002 & 2003 & 2004 & 2005 & 2006 & 2007 \\
\hline Banamex & 18,220 & 98,571 & 330,643 & 535,045 & 812,238 & $1,111,224$ & $1,616,461$ & $2,331,410$ \\
Bancomer & 23,908 & 81,378 & 185,728 & 282,075 & 474,413 & 805,199 & $1,324,453$ & $1,938,741$ \\
Confia Principal & 1,739 & 9,738 & 57,129 & 169,486 & 290,283 & 520,356 & 849,523 & $1,000,694$ \\
Ahorra Ahora & - & - & - & - & - & - & 70 & 181 \\
Argos & - & - & - & - & - & - & - & 8,017 \\
Coppel & - & - & - & - & - & - & 24,624 & 155,249 \\
Scotia & - & - & - & - & - & - & 0 & 15,263 \\
Metlife & - & - & - & - & - & 51,958 & 145,375 & 221,645 \\
HSBC & - & - & - & - & 306,725 & 677,058 & $1,000,247$ & $1,209,694$ \\
Inbursa & 3,486 & 7,344 & 21,704 & 94,162 & 257,187 & 651,860 & $1,073,042$ & $1,300,580$ \\
ING & - & 42,396 & 80,958 & 170,972 & 310,452 & 418,545 & 641,582 & 858,177 \\
Azteca & - & - & - & 16,114 & 71,078 & 242,809 & 499,726 & 531,042 \\
Afirme Bajio & - & - & - & - & - & 71 & 26,023 & 36,186 \\
Invercap & - & - & - & - & - & 49,460 & 231,904 & 511,698 \\
IXE & - & - & - & - & 3,911 & 17,685 & 46,738 & 82,452 \\
Profuturo GNP & 14,778 & 49,986 & 179,211 & 414,685 & 773,081 & $1,176,642$ & $1,655,254$ & $2,054,909$ \\
Solida Banorte Generali & 9,935 & 51,181 & 156,065 & 275,380 & 433,937 & 737,089 & $1,250,877$ & $1,559,985$ \\
XXI & 4,307 & 23,783 & 66,226 & 128,146 & 199,433 & 288,165 & 430,975 & 604,138 \\
\hline NOTE: All dates refer to the month of December. The numbers in the cells are accumulated from the previous 12 months. - Refers to \\
AFORES created after July 1997: Ahorra Ahora (Sep-2006), Argos (Jan-2007), Coppel (Jan-2006), Scotia (Dec-2006), Metlife (Mar- \\
2005), HSBC (Feb-2004), ING (Dec-2001), Azteca (Apr-2003), Afirme Bajio (Dec-2005), Invercap (Mar-2005), IXE (Jul-2004). \\
SOURCE: Comisión Nacional del Sistema de Ahorro para el Retiro (CONSAR). & &
\end{tabular}


Table 11- Investment portfolio composition of AFORES from 2000 to 2007 (\%)

\begin{tabular}{llll}
\hline & Government bonds & Non-Government bonds & International \\
\hline December 2000 & 91.10 & 8.90 & - \\
December 2001 & 87.85 & 12.15 & - \\
December 2002 & 83.10 & 16.90 & - \\
December 2003 & 82.30 & 17.70 & - \\
December 2004 & 82.60 & 17.40 & - \\
December 2005 & 82.15 & 16.85 & 1.61 \\
December 2006 & 72.81 & 17.20 & 10.01 \\
December 2007 & 69.00 & 21.03 & 9.92 \\
\hline
\end{tabular}

NOTE: Non-government bonds include corporate, financial institutions, and state’s debt. - Refers to instruments not allowed by the regulatory agency.

SOURCE: Comisión Nacional del Sistema de Ahorro para el Retiro (CONSAR).

Table 12- Real rates of return SIEFORE 1 by main pension fund managers from 2000 to 2007(\%)

\begin{tabular}{lllllllll}
\hline AFORE & 2000 & 2001 & 2002 & 2003 & 2004 & 2005 & 2006 & 2007 \\
\hline Banamex & 8.08 & 12.21 & 5.05 & 1.71 & 1.71 & 8.76 & 4.77 & 2.96 \\
Bancomer & 7.42 & 13.63 & 4.97 & 1.97 & 1.97 & 6.29 & 7.29 & 2.70 \\
Confia Principal & 7.99 & 13.00 & 5.27 & 1.82 & 1.82 & 7.07 & 8.13 & 1.84 \\
Ahorra Ahora & - & - & - & - & - & - & NA & 2.42 \\
Argos & - & - & - & - & - & - & - & 2.18 \\
Coppel & - & - & - & - & - & - & NA & 3.50 \\
Scotia & - & - & - & - & - & - & NA & 3.50 \\
Metlife & - & - & - & - & - & NA & 7.89 & 2.58 \\
HSBC & - & - & - & 1.44 & 1.44 & 6.54 & 8.45 & 2.27 \\
Inbursa & 7.62 & 11.36 & 3.86 & 2.76 & 2.76 & 6.48 & 4.27 & 3.85 \\
ING & - & - & 5.00 & 1.90 & 1.90 & 7.61 & 7.38 & 2.21 \\
Azteca & - & - & - & 2.42 & 2.42 & 7.23 & 4.99 & 2.75 \\
Afirme Bajio & - & - & - & - & - & NA & 7.07 & 3.40 \\
Invercap & - & - & - & - & - & NA & 8.59 & 3.04 \\
IXE & - & - & - & - & NA & NA & 9.32 & 2.51 \\
Profuturo GNP & 7.70 & 12.46 & 5.69 & 1.71 & 1.71 & 8.36 & 8.55 & 2.11 \\
Solida Banorte Generali & 7.73 & 13.29 & 6.00 & 1.28 & 1.28 & 6.82 & 7.84 & 3.20 \\
XXI & 7.91 & 13.44 & 5.29 & 1.42 & 1.85 & 7.64 & 7.05 & 2.23 \\
\hline
\end{tabular}

NOTE: All dates refer to the month of December. NA is not available. - Refers to AFORES created after July 1997: Ahorra Ahora (Sep-2006), Argos (Jan-2007), Coppel (Jan-2006), Scotia (Dec-2006), Metlife (Mar-2005), HSBC (Feb-2004), ING (Dec-2001), Azteca (Apr-2003), Afirme Bajio (Dec-2005), Invercap (Mar-2005), IXE (Jul-2004).

SOURCE: Comisión Nacional del Sistema de Ahorro para el Retiro (CONSAR). 
Table 13-Real rates of return SIEFORE 2 by main pension fund managers from 2004 to 2007 (\%)

\begin{tabular}{lllll}
\hline AFORE & 2004 & 2005 & 2006 & 2007 \\
\hline Banamex & 1.46 & 10.08 & 10.15 & 2.73 \\
Bancomer & 1.72 & 6.73 & 8.33 & 1.74 \\
Confia Principal & 1.58 & 8.38 & 9.49 & 1.51 \\
Ahorra Ahora & - & - & 7.33 & 2.09 \\
Argos & - & - & 7.96 & 0.76 \\
Coppel & - & - & 9.99 & 4.15 \\
Scotia & - & - & 7.93 & 3.11 \\
Metlife & - & - & 7.98 & 3.20 \\
HSBC & 1.20 & 7.93 & 8.49 & 2.52 \\
Inbursa & 2.51 & 7.13 & 4.63 & 3.96 \\
ING & 1.40 & 8.70 & 9.62 & 2.37 \\
Azteca & 2.17 & 7.40 & 7.13 & 1.81 \\
Afirme Bajio & - & 8.53 & 7.98 & 0.67 \\
Invercap & - & 13.90 & 11.24 & 2.17 \\
IXE & 0.88 & 9.17 & 8.75 & 1.13 \\
Profuturo GNP & 1.46 & 10.09 & 11.56 & 1.93 \\
Solida Banorte Generali & 1.04 & 7.65 & 7.73 & 2.03 \\
XXI & 1.61 & 9.67 & 9.29 & 1.66 \\
\hline
\end{tabular}

NOTE: All dates refer to the month of December. - Refers to AFORES created after July 1997:

Ahorra Ahora (Sep-2006), Argos (Jan-2007), Coppel (Jan-2006), Scotia (Dec-2006),

Metlife (Mar-2005), HSBC (Feb-2004), ING (Dec-2001), Azteca (Apr-2003), Afirme Bajio (Dec-2005), Invercap (Mar-2005), IXE (Jul-2004).

SOURCE: Comisión Nacional del Sistema de Ahorro para el Retiro (CONSAR). 
Figure 1-Persons registered in the PRA system, from 1998 to 2008

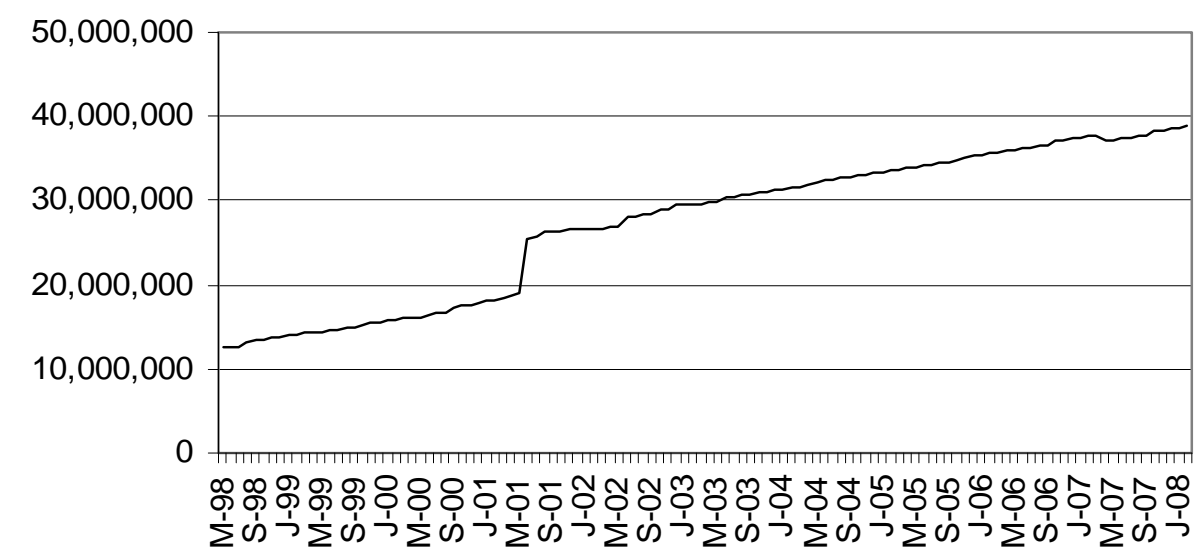

SOURCE: Comisión Nacional del Sistema de Ahorro para el Retiro (CONSAR).

Figure 2- Load factor fees, from 1998 to 2008

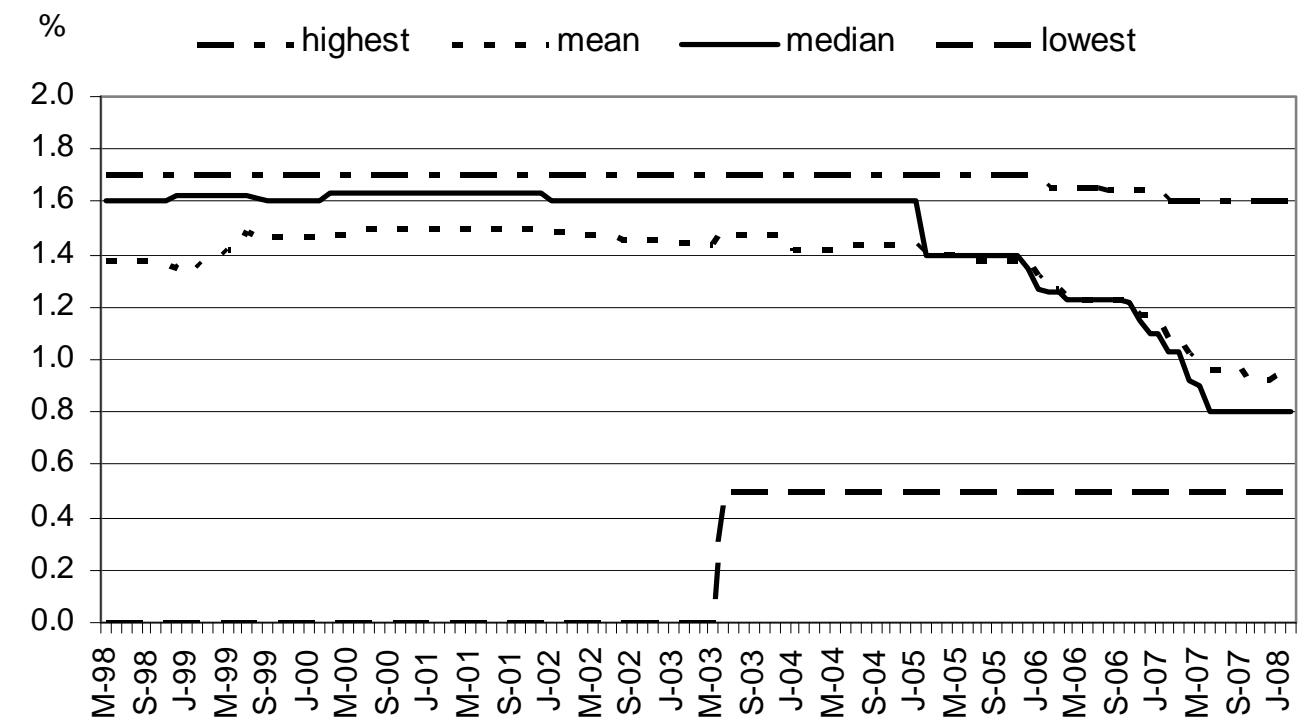

SOURCE: Comisión Nacional del Sistema de Ahorro para el Retiro (CONSAR). 
Figure 3- Balance fees from 1998 to 2008

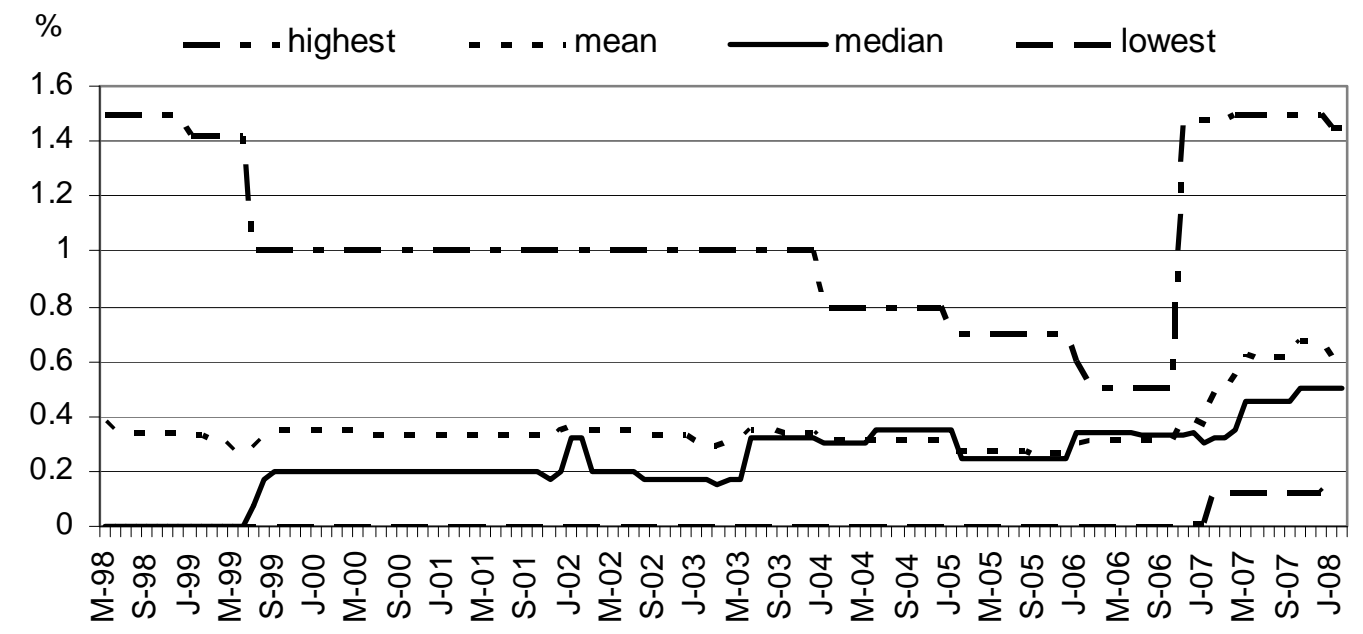

NOTE: Balance fees are an annual percentage.

SOURCE: Comisión Nacional del Sistema de Ahorro para el Retiro (CONSAR).

Figure 4- Interest fees from 1998 to 2008

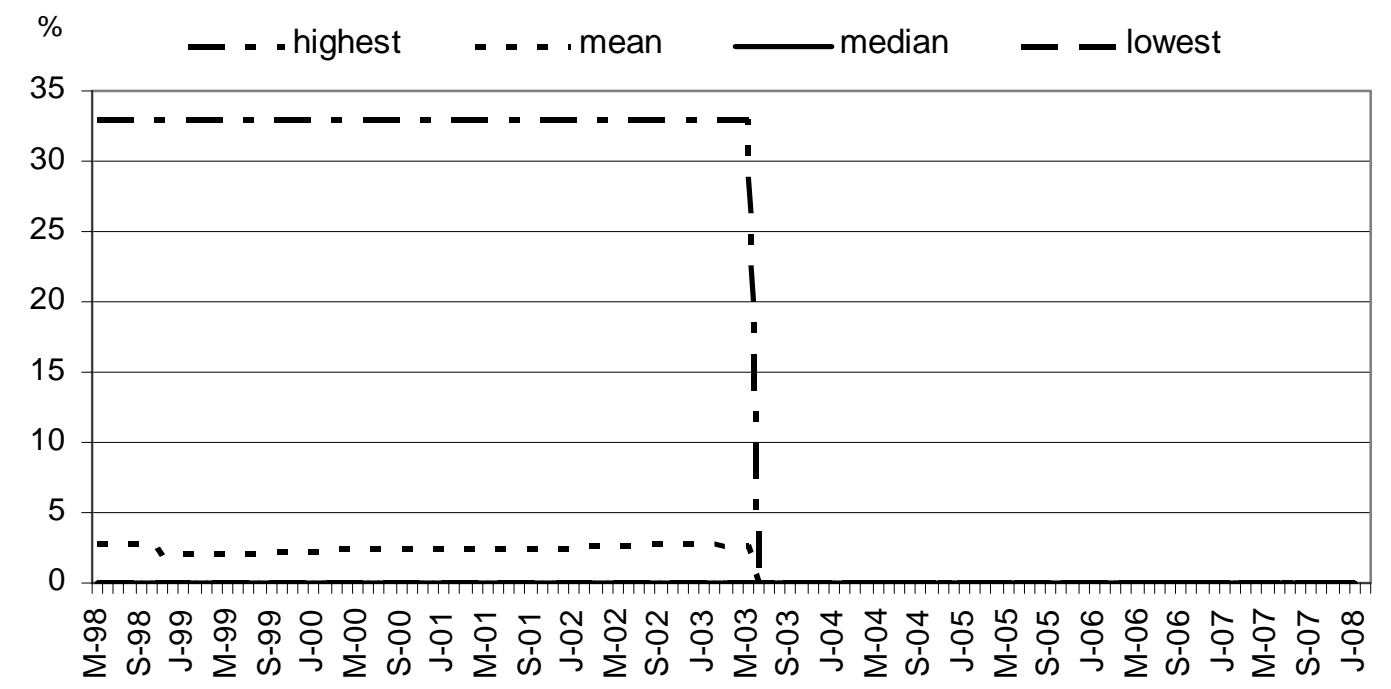

SOURCE: Comisión Nacional del Sistema de Ahorro para el Retiro (CONSAR). 
Figure 5- Proportion of switchers in the PRA system from 1999 to 2008

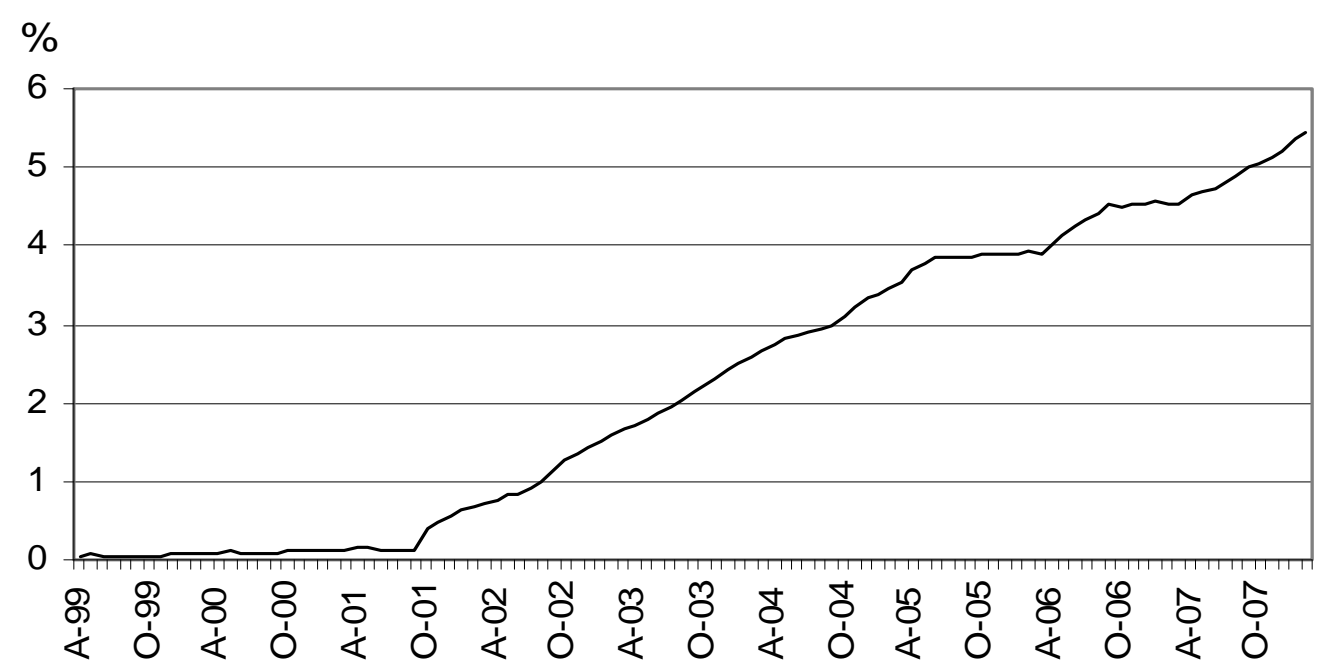

SOURCE: Author’s calculation using data from Comisión Nacional del Sistema de Ahorro para el Retiro (CONSAR).

Figure 6- Real interest of AFORES from 1998 to 2007

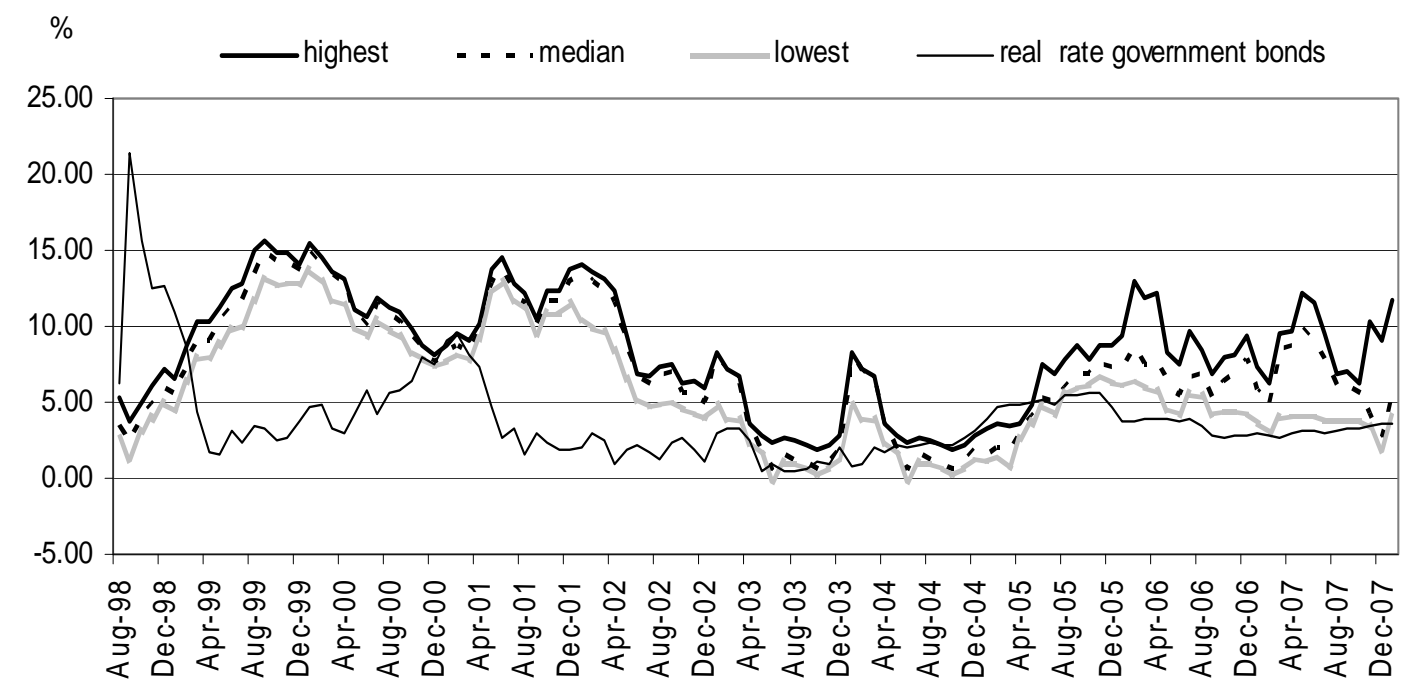

SOURCE: Comisión Nacional del Sistema de Ahorro para el Retiro (CONSAR) and Mexican Central Bank (BANXICO). 
Figure 7-Real interest of Siefore 1 and Siefore 2 from 2004 to 2007

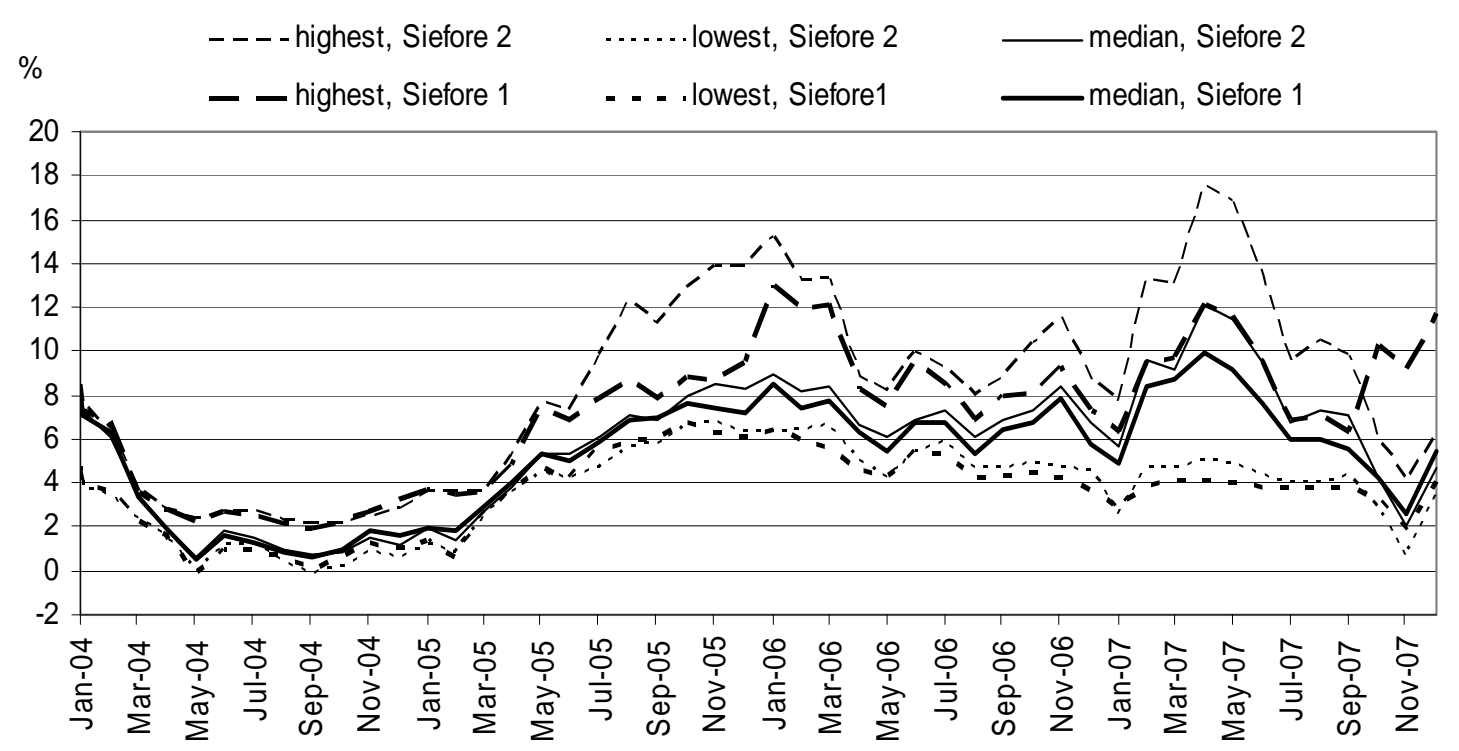

SOURCE: Comisión Nacional del Sistema de Ahorro para el Retiro (CONSAR).

Figure 8-Loss of pension funds due to load factor fees for a median worker by AFORE 


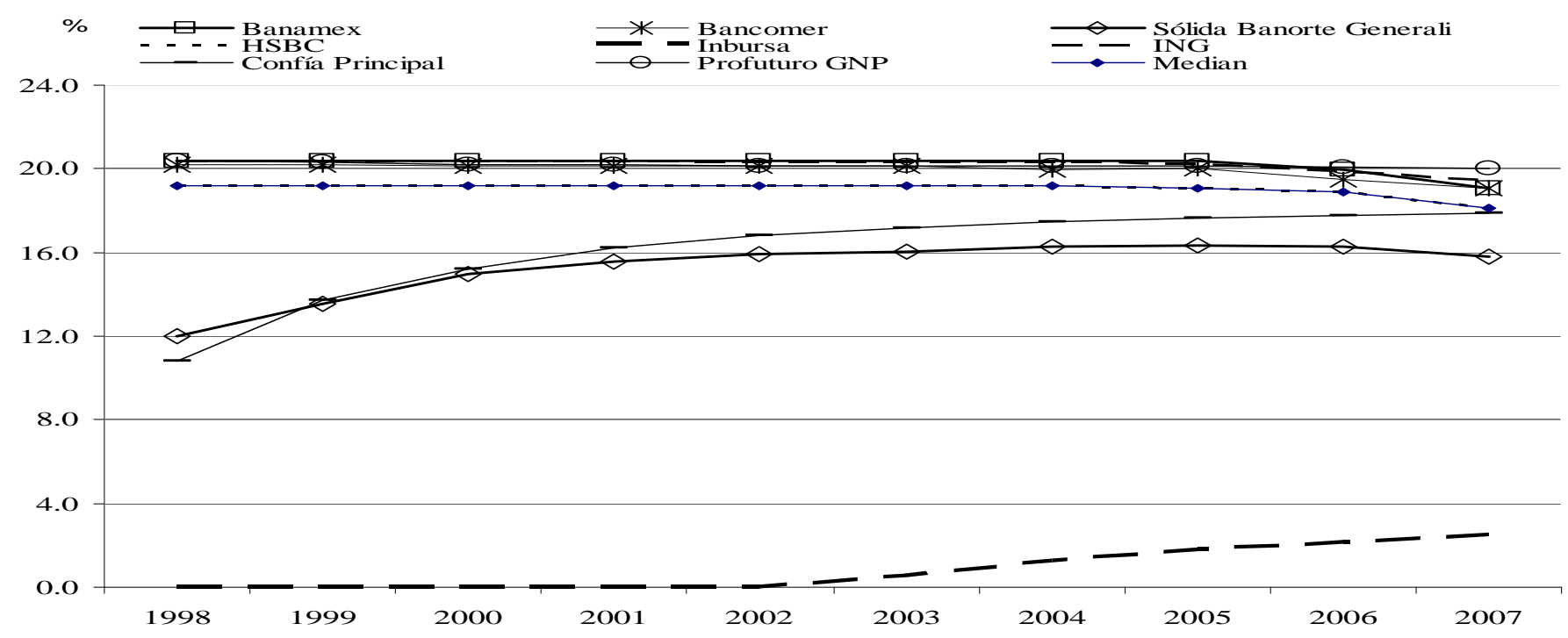

SOURCE: Author's calculation using data from Comisión Nacional del Sistema de Ahorro para el Retiro (CONSAR).

Figure 9-Loss of pension funds due to balance fees for a median worker by AFORE

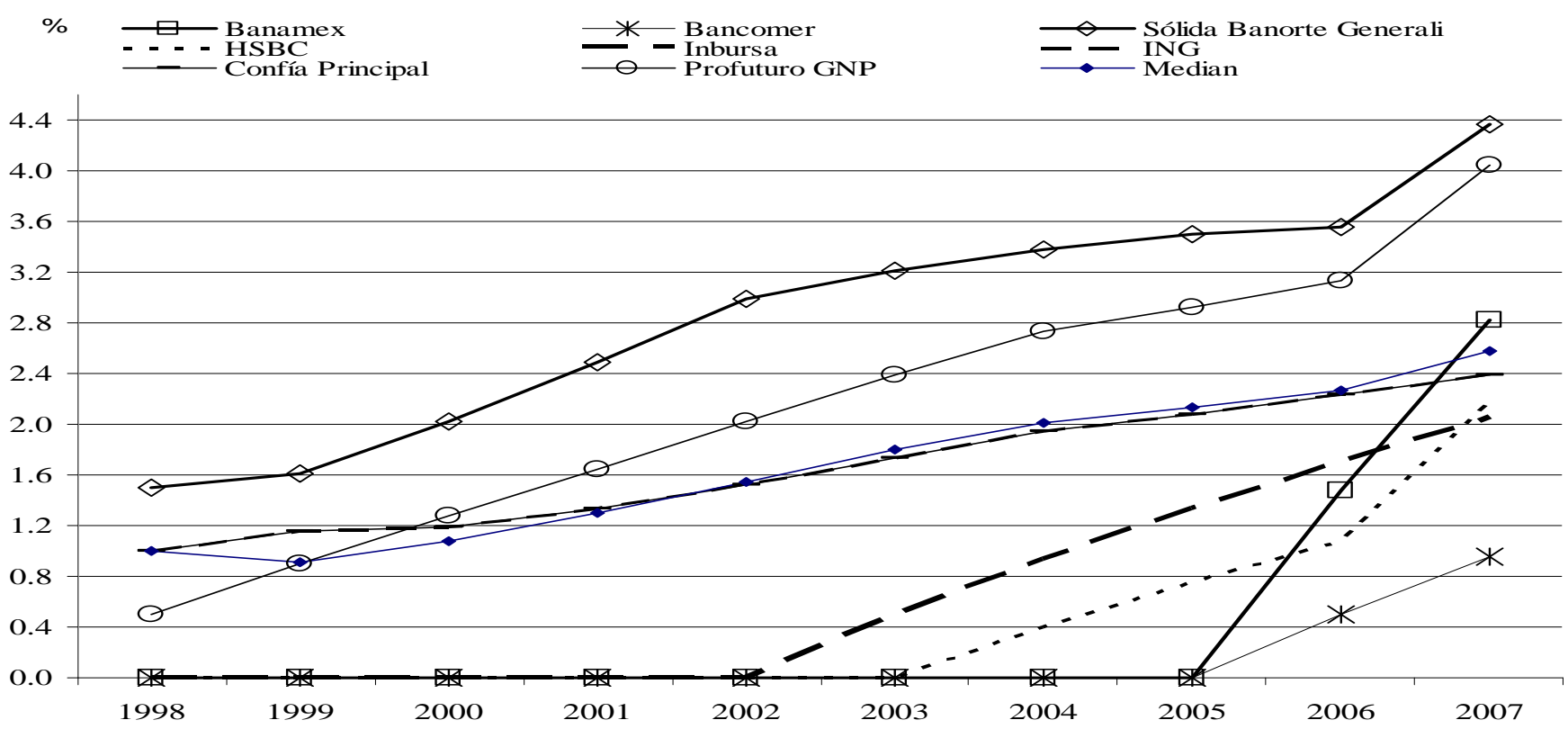

SOURCE: Author’s calculation using data from Comisión Nacional del Sistema de Ahorro para el Retiro (CONSAR). 
Figure 10-Loss of pension funds due to interest fees for a median worker by AFORE

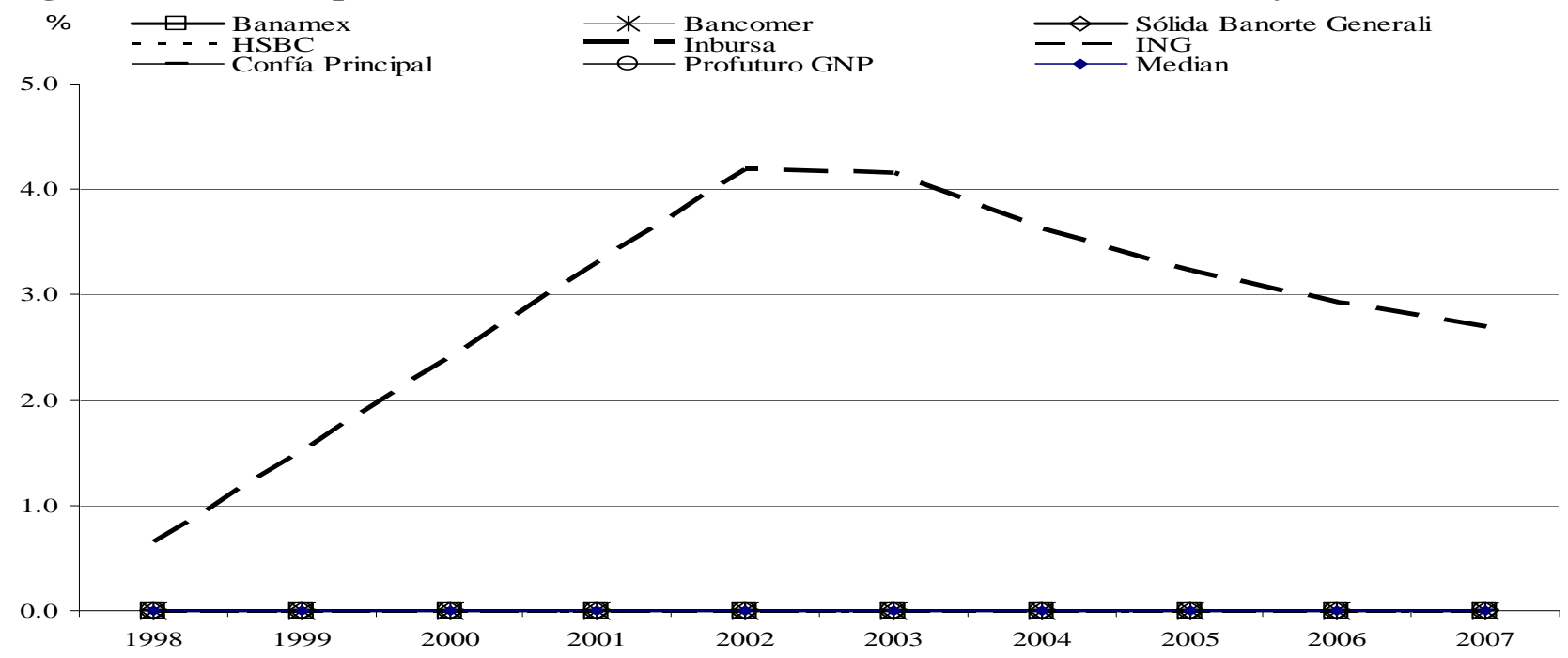

SOURCE: Author's calculation using data from Comisión Nacional del Sistema de Ahorro para el Retiro (CONSAR).

Figure 11-Loss of pension funds due to load factor fees including discounts for tenure for a median Worker by AFORE

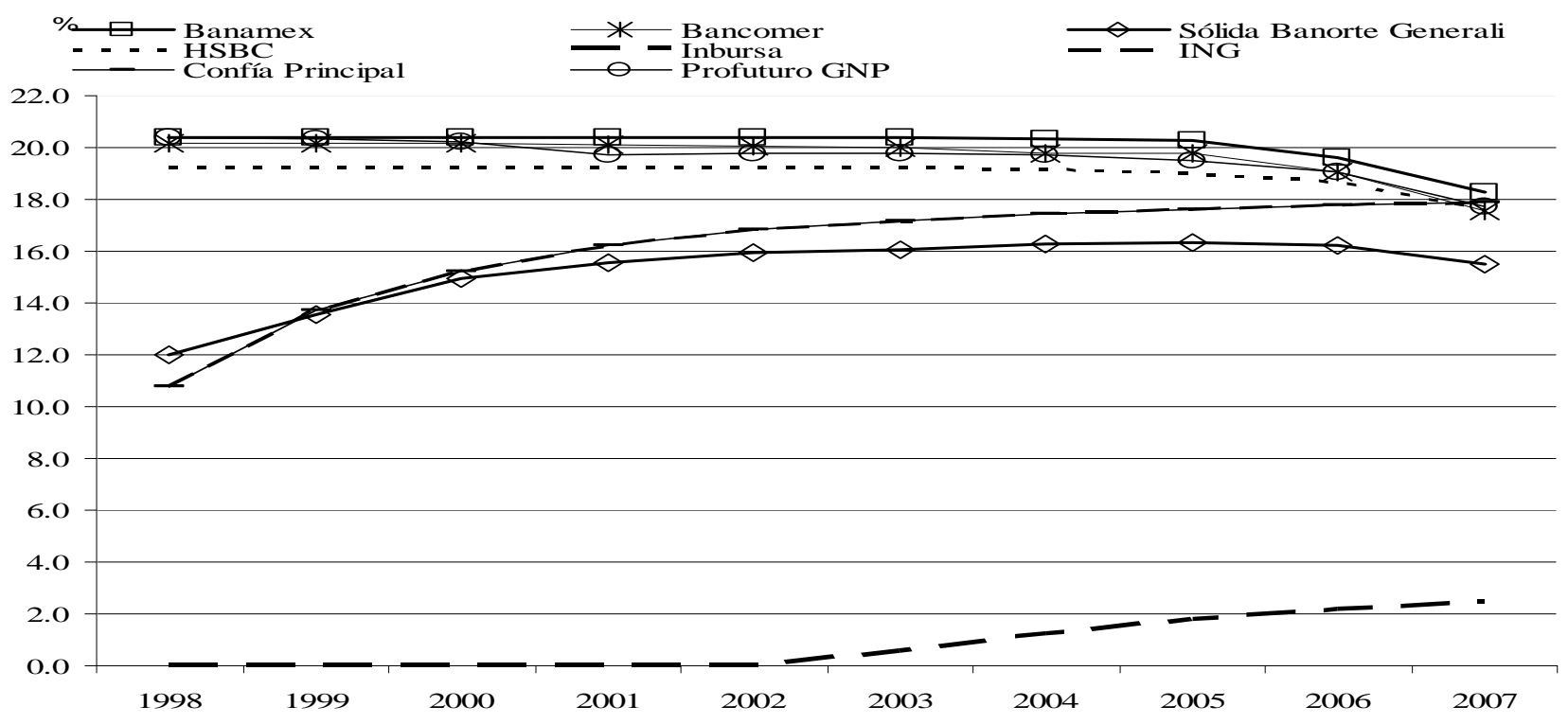

SOURCE: Author’s calculation using data from Comisión Nacional del Sistema de Ahorro para el Retiro (CONSAR). 
Figure 12-Loss of pension funds due to load factor, balance, and interest fees for a median worker by AFORE

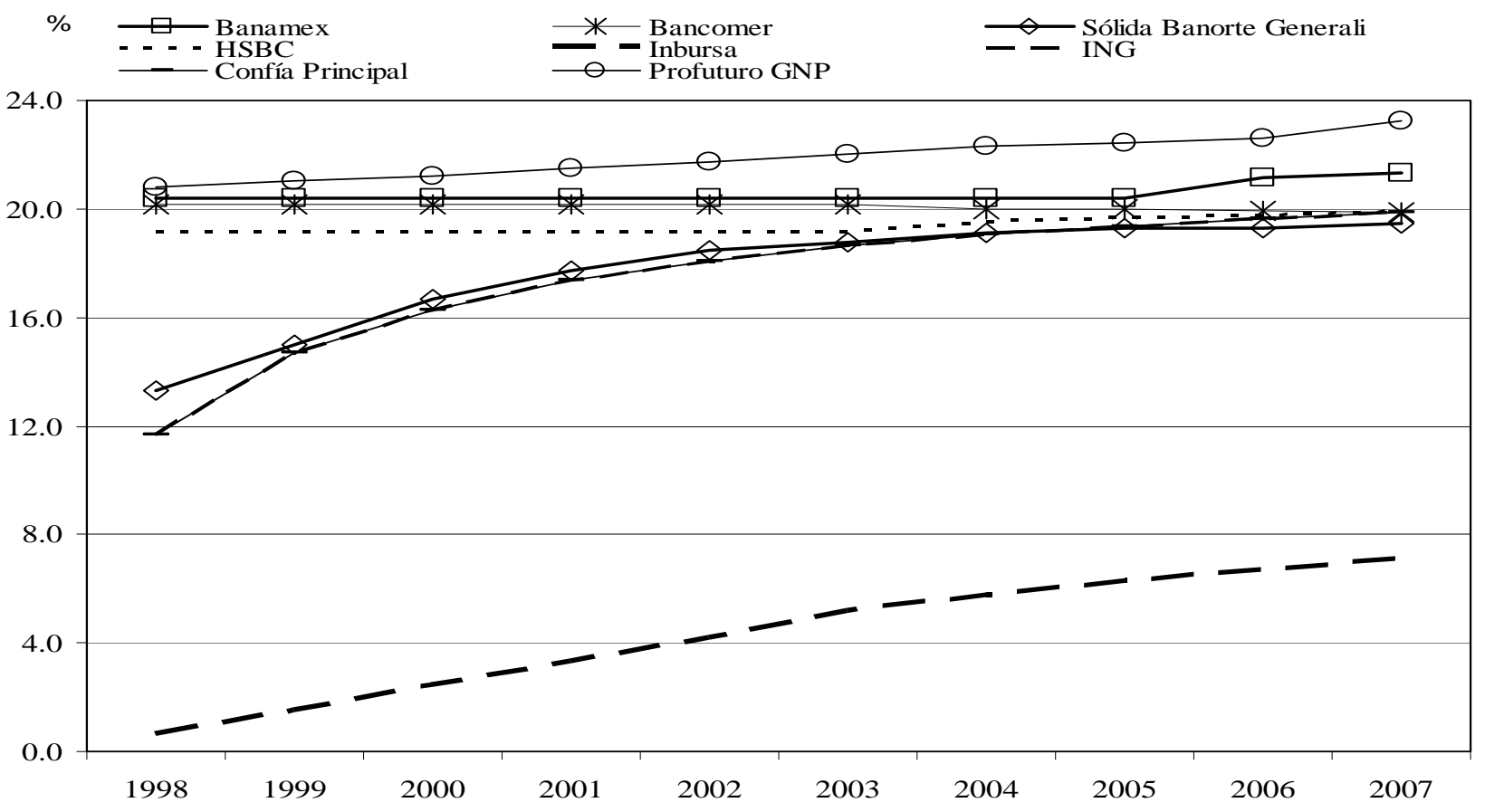

SOURCE: Author's calculation using data from Comisión Nacional del Sistema de Ahorro para el Retiro (CONSAR). 